\title{
"This was not the time for this type of 1890 imperialism": Cryolite, Control, and Canada-US Relations over Greenland, 1940
}

\section{Gordon W. Smith, introduced and edited by P. Whitney Lackenbauer}

This article is drawn from the unpublished second volume of Gordon Smith's magnum opus, A Historical and Legal Study of Sovereignty in the Canadian North and Related Law of the Sea Problems. Edited and introduced by P. Whitney Lackenbauer, this article explores Canada-United States relations over Greenland in 1940, particularly whether Canada or the United States would secure de facto control over Greenland and its unique supply of cryolite, essential for the production of aluminum at that time. In doing so, Smith contributes to our understanding of how competing interests and priorities made Greenland a site of rivalry and ultimately compromise between Second World War allies.

Cet article est tiré du deuxième volume inédit du grand ouvrage de Gordon Smith, intitulé A Historical and Legal Study of Sovereignty in the Canadian North and Related Law of the Sea Problems. Édité et présenté par P. Whitney Lackenbauer, cet extrait traite des relations canado-américaines relatives au Groenland en 1940, en particulier du contrôle de fait éventuel par le Canada ou les États-Unis du Groenland et de son unique approvisionnement en cryolite, essentielle à la production d'aluminium à l'époque. Ainsi, Smith nous aide à mieux comprendre la façon dont les priorités et les intérêts divergents ont fait du Groenland un site de rivalité et, en fin de compte, de compromis entre les alliés de la Seconde Guerre mondiale.

The Northern Mariner / Le marin du nord 31, no. 3 (Autumn 2021), 241-84 
Gordon W. Smith, Ph.D. (1918-2000) dedicated much of his life to researching Canada's sovereignty in the Arctic. This article is drawn from the second volume of his magnum opus, A Historical and Legal Study of Sovereignty in the Canadian North and Related Law of the Sea Problems, which was written over three decades and remained incomplete at the time of his death in October 2000. His research provides meticulously grounded insights into Canada-United States relations over Greenland, the northeastern and northwestern staging routes, the Alaska Highway, and the Canol pipeline project. While much of his work details Canadian actions to identify and address sovereignty concerns related to the massive program of USled defence and development projects in the Canadian North during the war, this particular story from 1940 revolved around whether Canada or the United States would secure de facto control over Greenland and its unique supply of cryolite, essential for the production of aluminum at that time.

The wartime exchanges between Ottawa and Washington over the world's largest island played out through quiet diplomacy, never inviting public debate or excessive political turmoil. Nevertheless, the episode reveals deep-seated misapprehensions on the part of officials in Ottawa and Washington about their counterparts' intentions. " "The Canadian-American dispute subsided almost as quickly as it had flared," political scientist David Haglund observed in a 1981 article on the subject, but he found it ironic that policymakers and scholars trumpeted the eventual resolution of the affair as an example of close bilateral cooperation. Haglund thought it "anything but an instance of cooperation," owing as much to conflicting national interests as it did to mutual perceptions."'

In this article, Gordon W. Smith paints a more nuanced portrait, drawing upon a deeper source base and highlighting how the episode inherently related to the maritime connections between Greenland, the United States, and Canada. Although Smith does not discuss the 1940 voyage of the RCMP ship St. Roch in the context of Greenland, it was, at least in part, motivated by the need to defend Greenland in the face of increased German activity in the North Atlantic, concern over the

1 On Greenland during the Second World War, see David Howarth, The Sledge Patrol: A WWII Epic of Escape, Survival, and Victory (New York: Macmillan, 1957); Nancy Fogelson, "Greenland: Strategic Base on a Northern Defense Line," Journal of Military History 53, no. 1 (1989): 51-63, https://doi.org/10.2307/1986019; Stetson Conn, Rose Engelman, and Byron Fairchild, Guarding the United States and its Outposts (Washington: United States Army Center of Military History, 2000), 442-458; Wilhelm Dege, War North of 80: The Last German Arctic Weather Station of World War II, trans. William Barr (Calgary: University of Calgary Press, 2004); Axel Kjær Sørensen, DenmarkGreenland in the Twentieth Century (Copenhagen: Museum Tusculanum Press, 2007); and Shelagh Grant, Polar Imperative: A History of Arctic Sovereignty in North America (Vancouver: Douglas and McIntyre, 2010).

2 David Haglund, “Plain Grand Imperialism on a Miniature Scale': Canadian-American Rivalry Over Greenland in 1940," American Review of Canadian Studies 11, no. 1 (1981): 15, https://doi. org/10.1080/02722018109480718. For a response, see Michael Scheuer, "On The Possibility That There May Be More To It Than That: Professor Haglund, the Documents On Canadian External Relations Series And The Canadian-American Controversy Over Greenland In 1940," American Review of Canadian Studies 12, no. 3 (1982): 72-83, https://doi.org/10.1080/02722018209480759. 
security of the island's cryolite mines (crucial in the production of aluminum), and the possibility that a Canadian occupation force might have to be deployed, supplied, and supported. ${ }^{3}$ As historian Dawn Berry explains, the location of the cryolite mine presented logistical challenges that attracted the attention of North American officials:

Ivigtut is located just below the Arctic circle on Greenland's south west coast, and the operations of the mine were largely contingent on local environmental conditions. For example, Ivigtut's harbour was frozen for at least eight months of the year, leaving a brief three to four month window when the mineral could be shipped to global markets. In 1940, Ivigtut's geography posed an additional challenge as the ongoing war at sea was inflicting heavy losses on Allied shipping in the North Atlantic, further complicating existing issues of cryolite distribution in the period. ${ }^{4}$

Canada's plans for Force " $X$ " contemplated sending soldiers by ship to secure critical infrastructure in Greenland - an idea that the still-neutral United States fervently opposed, worrying that it could set a precedent for Japanese occupations in Dutch and French Southeast Asia. The article reveals the close relationship between government and industry at a critical moment of the war, with the Aluminum Company of Canada (Alcan) and the Pennsylvania Salt Manufacturing Company lobbying their respective federal officials to promote their interests and secure their commodity supply chains. ${ }^{5}$

Smith also documents the roles of the Department of Transport icebreaker N.B. McLean and the Hudson's Bay Company ship Nascopie in seeking to open trade between Canada and Greenland as a way to strengthen relations. As Smith recounts, Greenlandic authorities - backed by two plain clothed members of the

3 On the wartime voyages of St. Roch, see Gordon W. Smith, A Historical and Legal Study of Sovereignty in the Canadian North: Terrestrial Sovereignty, 1870-1939, ed. P. Whitney Lackenbauer (Calgary: University of Calgary Press, 2014), 376; Shelagh D. Grant, "Why the St. Roch? Why the Northwest Passage? Why 1940? New Answers to Old Questions," Arctic 46, no. 1 (March 1993): 82-87, https://doi.org/10.14430/arctic1326; Shelagh Grant and P. Whitney Lackenbauer, "The Adventurous Voyage”: St. Roch and the Northwest Passage, 1940-42 and 1944 (Antigonish: Mulroney Institute on Government Arctic Operational History Series, vol. 7, 2019); and Peter Kikkert and P. Whitney Lackenbauer, “'On Hallowed Ground': St. Roch, Sovereignty, and the 1944 Northwest Passage Transit,” Northern Mariner XXIX, no. 3 (Fall 2019): 213-32.

4 Dawn Berry, "Business interrupted: remote resources and environmental knowledge flows in times of global crisis (Alcan and Greenland 1940-1945)," Business History 59, no. 7 (2017): 1035, https://doi.org/10.1080/00076791.2016.1174693.

5 See, for example, D. Campbell, Global Mission: The Story of Alcan (Montreal: Alcan Aluminium, 1989); Dawn Berry, "Cryolite, the Canadian aluminium industry and the American occupation of Greenland during the Second World War," Polar Journal 2, no. 2 (2012): 219-235, https://doi.org/10.1080/2154896X.2012.735037; Barry, "Business interrupted"; R.K. Leavitt, Prologue to Tomorrow: A History of the First Hundred Years in the Life of the Pennsylvania Salt Manufacturing Company (Philadelphia: Pennsylvania Salt Manufacturing Co., 1950); and Matthew Evenden, "Aluminum Commodity Chains and the Environmental History of the Second World War," Environmental History Review 16, no. 1 (2011): 69-93, https://doi.org/10.1093/envhis/emq145. 


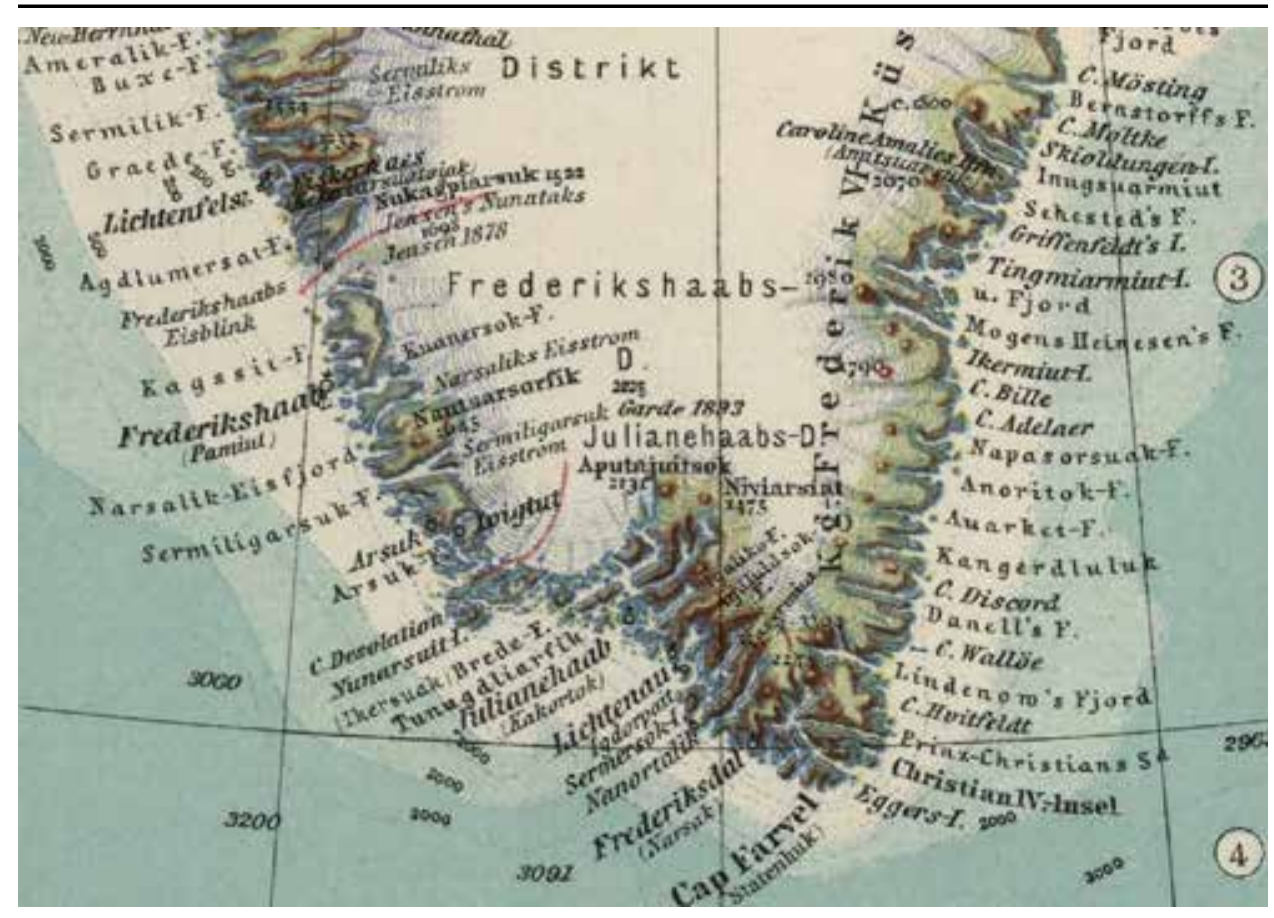

Detail of southern Greenland, circa. 1940 (Stielers Hand-Atlas, (1940) Plate 39)

US Coast Guard Cutter Comanche - did not permit the crew of Nascopie to go ashore at Ivigtut for three weeks, until after the island's governors nationalized the cryolite mine. While they waited, Penn Salt formalized a distribution agreement with the mine and American forces established themselves as its protectors. The Americans - who had stridently opposed Canadian occupation of Greenland essentially did so themselves, and by April 1941 signed an agreement with the free Danish Ambassador in Washington to formalize the arrangement. Smith explains how this happened, contributing to our understanding of how competing interests and priorities made Greenland a site of rivalry and ultimately compromise between Second World War allies.

$$
* * *
$$

The fall of Denmark on 9 April 1940 left Greenland in a highly vulnerable position, exposed to pressure from and occupation by either belligerent powers or the neutral United States. Great Britain, Germany, Canada, and the United States were all vitally interested in Greenland's fate, and for the North American nations in particular the sudden disruption of Danish rule over the island meant a great deal of involved diplomatic and other activity, largely cooperative but also partly competitive, during the months that followed.

The main importance of Greenland in the Second World War lay in its geographical location, in that airplanes flying the shortest Great Circle route 
between major North American and British centres passed either directly over the island or fairly close to its southern extremity, depending upon their bases of departure and arrival. Similarly, ships of all kinds sailing the shortest North Atlantic route passed surprisingly close to its southern tips. Greenland thus had much to offer as a huge site for air and radio stations and naval bases and for meteorological installations to be used as need dictated for refuelling, rest, and refuge purposes, for the protection of convoys, for weather forecasting, and for the location of enemy warships and submarines. In these respects, the importance of Greenland to the Allies was augmented greatly after the Nazi conquest of northwestern Europe in the spring of 1940, when the problems of maintaining trans-Atlantic communications greatly increased. In German hands Greenland would provide bases from which long-range bombing attacks could be delivered into the heart of North America - a matter of as much concern to the United States as to Canada - and from which ships and planes en route to and from Great Britain could be subjected to continual harassment and depredation. The persistence with which the Nazis sought to establish and maintain meteorological stations in remote parts of Greenland during the war testifies to the high priority they gave to getting weather information from this region. In an economic sense, Greenland was of crucial importance as the world's principal source of natural cryolite, a mineral essential in the production of aluminum and consequently of airplanes.

Fortunately for Greenland, the Danish government had made certain provisions to take care of emergency situations such as that which arose in April 1940. Anticipating difficulty in maintaining the flow of necessary supplies under wartime conditions, the so-called "Greenland Administration" in Copenhagen had shipped substantial extra stocks of foods and materials to the island the previous year. As for administration of the colony in the event of a breakdown in communications with the mother country, emergency measures had been provided for in the Greenland Constitution of 1925. Article 10, Paragraph 3 of this document was framed in the following terms: "The Administrators, as the representatives of the Danish Government in Greenland, are to be considered the responsible authority in the country and can in exceptional instances take such measures as the interests of the population may demand." Accordingly, two "Administrators" or "Landsfogeder" in Greenland took over the administration of the island on 23 April, knowing that their action had the approval of the home government. Meanwhile, under the initiative of the Danish Minister in Washington, Henrik de Kauffmann, an "American-Danish Greenland Commission" was being organized and its existence was announced on 25 April. It had American and Danish representation and was designed mainly to look after Greenland's supplies and trade. ${ }^{7}$

6 Quoted in M.J. Dunbar, "Greenland During and Since the Second World War," International Journal 5, no. 2 (1950): 125, https://doi.org/10.1177/002070205000500203.

7 Sometime later the American-Danish Greenland Commission was replaced by the "Greenland Delegation," with headquarters in New York. Dunbar, "Greenland During and Since the Second World War," 124-26. See also Erling Porsild, "Greenland at the Crossroads," Arctic 1, no. 1 (1948): 
The occupation of Denmark posed for both Canada and the United States the question of what action should be taken respecting Greenland. In conversation on 10 April, President Roosevelt and the Danish Minister in Washington, Henrik Kauffmann, agreed that Greenland belonged to the North American continent, ${ }^{8}$ but at a press conference on 12 April the president declined to answer questions about the applicability of the Monroe Doctrine, committing the United States only to the sending of relief supplies. ${ }^{9}$ The hesitation appears to have been only momentary; on the same day Secretary Hull stressed the applicability of the Monroe Doctrine to Greenland, ${ }^{10}$ and quickly the American government made it clear that it would pursue its traditional "hands-off" policy respecting the government of the island, for itself and for others.

As a belligerent, Canada felt a greater sense of urgency about the security of Greenland than the United States did and was more inclined to take hasty measures to safeguard it. Immediately after the occupation of Denmark, the Aluminum Company of Canada contacted the Department of External Affairs, stressing the necessity of protecting the cryolite mines and urging that immediate action to this end be taken, in which case the company would be "only too glad to ... operate these mines for the benefit of the allies." 11 The company's stand was strengthened by a telegram from Geoffrey Cunliffe, Aluminum Controller for Great Britain, emphasizing the importance of obtaining maximum supplies of aluminum from Canada in view of the disasters that had befallen the Scandinavian countries. ${ }^{12}$ Already, on 9 April, the Department of External Affairs had sent a cable to the Secretary saying that enemy ships were reported to be heading for Greenland and drawing attention to the danger of enemy interference with cryolite production at Ivigtut. $^{13}$

55, https://doi.org/10.14430/arctic3997.

8 William Langer and S. Everett Gleason, Challenge to Isolation (New York: Harper and Brothers, 1952), 430.

9 Langer and Gleason, Challenge to Isolation, 430. See report on Roosevelt's April 12 press conference in the Washington Daily News, 12 April 1940; clipping in RG 25, file 8559, microfilm reel no. C-8365, Library and Archives Canada (LAC). And see article entitled "Roosevelt Studies Greenland Status," The Polar Times, no. 11 (Dec. 1940): 8.

10 Langer and Gleason, Challenge to Isolation, 430. The authors quote a memo written by Harley Notter of the State Department to Benjamin Sumner Welles on April 9, saying that there could be no doubt that the Monroe Doctrine applied directly to Greenland and Iceland. See also Cordell Hull, The Memoirs of Cordell Hull, vol. I (New York: Macmillan Co., 1948), 753, 754-55.

11 F.W. Bruce (for Aluminum Co. of Canada Ltd.) to Norman Robertson, 9 April 1940, RG 25, file 8559 , microfilm reel no. C-8365, LAC. Evidently the original papers have been destroyed, and the microfilm records appear to be rather mixed up. Bruce wrote another urgent letter to Robertson on April 11, and on the same day Robertson put the substance of his two letters in a memo to Skelton.

12 Cunliffe to President Powell of Aluminum Co. of Canada, secret Dispatch No. 609, 11 April 1940 and Robertson to Skelton, 11 April 1940, RG 25, file 8559, microfilm reel no. C-8365, LAC.

13 Secretary of State for External Affairs to Secretary of State for Dominion Affairs, No. 47, 9 April 1940, RG 25, vol. 2732, file 267-J-40C, LAC; also in David. R. Murray, ed., Documents on Canadian External Relations [hereafter DCER], vol. 7, pt. 1, 1939-1941 (Ottawa: Department of External Affairs, 1974), doc. no. 1105, 948. 


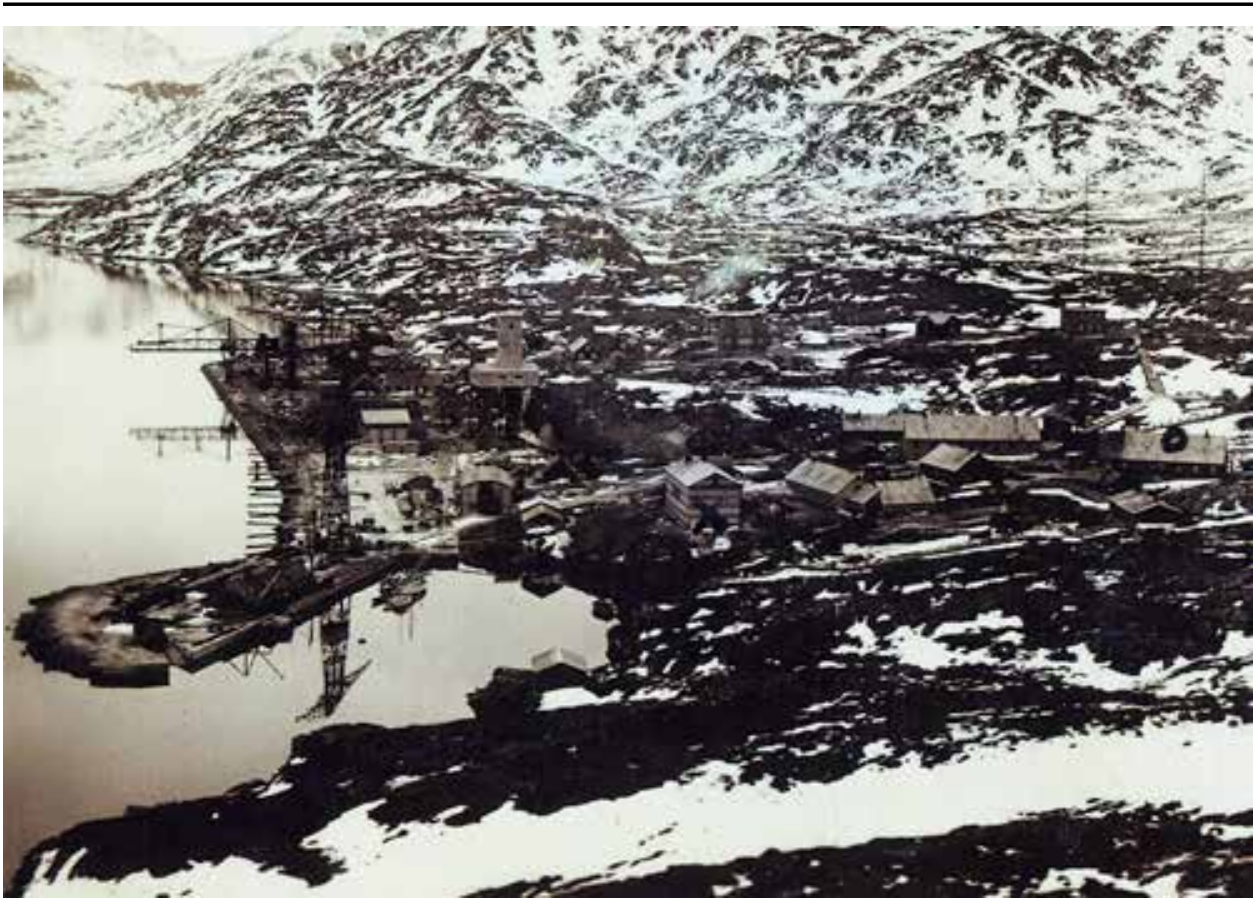

Postcard of Ivigtut from the 1930s.

On 10 April the Department of External Affairs wrote a memo for Prime Minister William Lyon Mackenzie King suggesting that the question of protective action would probably arise, that such action would be more acceptable to the United States if it were by Canada than if it were by Great Britain or France. ${ }^{14}$ On 11 April, senior advisor Oscar D. Skelton sent copies of relevant documents to the Department of National Defence in Ottawa, obviously anticipating that action by this department might be in the offing. ${ }^{15}$ The next day, Dr. Hugh Keenleyside advanced the opinion that, from the viewpoint of international law, whatever legal position Germany had established for herself in Denmark as a result of her occupation, the Allies were fully justified in regarding Greenland as enemy territory. Summarizing the value of Greenland to the Allied war effort and the reasons why Germany should not be permitted to establish herself there, he then suggested that "at least two or three small naval and air bases on the Greenland coast" should be set up, one of which should be at Ivigtut. In the belief that a British occupation of the island would provoke "an outburst of anti-British sentiment" in the United

14 Department of External Affairs to Prime Minister William Lyon Mackenzie King, RG 25, vol. 2731, file 267-J-40C, vol. 1, LAC; DCER, 1939-1941, doc. no. 1106, 948-50. The document is initialled by Skelton.

15 Skelton to Acting Deputy Minister Naval and Air Services, DND, 11 April 1940, RG 25, file 8559, microfilm reel no. C-8365, LAC. 
States, largely because it would be regarded as a violation of the Monroe Doctrine, and that on the contrary Canadian defensive action would be favourably regarded there, he suggested that the job should be done by Canada. An early decision, he added, was "imperative." 16

On 11 April Skelton sent a memo to the prime minister, enclosing information about cryolite from the Aluminum Company of Canada, and also a press dispatch "showing Washington is getting interested in Greenland." He asked if National Defence should be requested "to report on the feasibility of taking effective action in Greenland, with of course the United Kingdom covering in the north Atlantic?"17 On the authority of an argument in Council that same day that, in the absence of the Minister of National Defence (Norman Rogers), Acting Minister J.L. Ralston should consult with Chief of the Naval Staff Rear Admiral Percy Nelles on the question of military intervention, ${ }^{18}$ Ralston talked with both Nelles and Chief of the General Staff Maj. Gen. T.V. Anderson on the morning of 12 April. Nelles's initial reaction was that the Department of Transport's Marine Service icebreaker N.B. McLean, with naval and military personnel, might be sent to protect the mine, and that Germany would not be able to send a large vessel. Any intervention would have to include taking charge of civil administration on the long western coast. Anderson took approximately the same view. Skelton prepared and sent to Prime Minister King drafts for "some preliminary inquiries in London and Washington." 19 Keenleyside immediately interviewed Alf Erling Porsild, a Danish-born Canadian citizen (he had become naturalized in 1931) who had lived in Greenland and supplied relevant information to anticipated developments, notably that the harbour of Ivigtut was ice-free year round, that there were no airfields in Greenland, that fogs and bad weather made the use of seaplanes extremely unreliable, and that there were many safe harbours and havens along the coast which German submarines could easily use. ${ }^{20}$

Planning in the Department of National Defence for some kind of military intervention in Greenland began as soon as the senior officials of the department had been contacted for consultation purposes. On 12 April, the Director of Military Operation and Intelligence (DMO and I) Col. Maurice Pope sent a "brief and hasty

16 Memo by H.L. Keenleyside, "Canada, Greenland, and the Monroe Doctrine," 11 April 1940, RG 25, file 8559, microfilm reel no. C-8365, LAC.

17 Skelton to King, 11 April 1940, RG 25, vol. 2731, file 267-J-40C, vol. 1, LAC.

18 Skelton to Acting Deputy Minister Naval and Air Services, DND, 12 April 1940, RG 25, vol. 2731, file 267-J-40C, vol. 1, LAC.

19 Skelton to King, 12 April 1940, RG 25, vol. 2731, file 267-J-40C, vol. 1, LAC. See also in DCER, 1939-1941, vol. 7, pt. 1, doc. no. 1108, 953-54. Anderson recorded his thoughts on the matter in a memo to file on the same day. H.Q.S. 8559, Anderson to file, 12 April 1940, RG 25, vol. 2731, file 267-J-40C, vol. 1, LAC.

20 Skelton to R.A. Gibson, 12 April 1940, RG 25, vol. 2731, file 267-J-40C, vol. 1, LAC; Gibson to Skelton, 12 April 1940, RG 25, file 8559, microfilm reel no. C-8365, LAC; Memo by Keenleyside, "Information Regarding Greenland," 12 April 1940, RG 25, file 8559, microfilm reel no. C-8365, LAC. 
appreciation" to the CGS in which he visualized an expedition to Ivigtut containing an army component which would total approximately 360 all ranks. ${ }^{21} \mathrm{~A}$ day later, Commander J. Roy of the Royal Canadian Navy (RCN) wrote a memo for his service chief recommending that a naval party of thirty to forty men be sent, that the N.B. McLean armed with 4-inch guns be used in preference to a navy ship, and that a small force of Royal Canadian Mounted Police (RCMP) be sent to occupy Godhavn, Godthaab, and Ivigtut. Actual defence of the cryolite mine should be an army responsibility. He agreed strongly with the argument in Keenleyside's memo that Greenland should now be treated as enemy territory and occupied.22 With these papers as starting points, planning went on during the next several days, mainly in a joint planning subcommittee comprising Pope and Roy as army and navy representatives respectively, and Wing Commander J.A. Lawrence as representative of the RCAF. After several drafts they framed a plan to send an advance party totalling 100 men (including personnel from the three services and the RCMP) in the N.B. McLean, which was to be taken over by the Navy, outfitted at Quebec, and dispatched to Ivigtut as quickly as possible. This advance party was to be followed early in June by a defence force comprising one composite infantry company plus supporting army units. The plan was revised slightly and signed on 15 April by the Chief of Staff, who presented it on the same day to Colonel Ralston (then Acting Prime Minister in the absence of King, who had gone to the United States for a holiday). ${ }^{23}$

Just before King left, Skelton had found him considerably less than enthusiastic over the idea of precipitate action in Greenland. The prime minister's view was that "we should not jump into the position of announcing we were ready to take over Greenland," citing the impossibility of foreseeing the consequences, the possibility of similar involvement with Newfoundland, adverse American reaction, and the likely need to send more troops to Europe. Instead, King preferred simply informing the British government of the danger and "let[ting] them take the necessary action." Skelton conceded that any possible action must be carefully considered and that it should be "purely precautionary and temporary," adding that provision of the usual supplies for the Greenlanders should be kept in mind. To this, King replied that "the unemployed in Canada would criticize looking after Esquimaux in Greenland's icy mountains, or India's coral strand rather than Canadians at home." However, he later approved the draft telegram with a slight amendment. ${ }^{24}$

21 Pope to CGS, 12 April 1940, RG 25, file 8559, microfilm reel no. C-8365, LAC.

22 Roy to CNS, 13 April 1940 and Roy to Keenleyside, 13 April 1940, RG 25, vol. 2731, file 267-J-40C, vol. 1, LAC.

23 Joint Planning Sub-Committee drafts, April 13 and 14; CSC report, 15 April, and note Pope to CSC, 15 April 1940, RG 25, file 8559, microfilm reel no. C-8365, LAC.

24 Memo for Skelton, 12 April 1940, RG 25, vol. 2731, file 267-J-40C, vol. 1, LAC; also DCER, 1939-1941, vol. 7, pt. 1, doc. no. 1109, 954. King himself made no mention of this conversation in his diary entry for that day. Actually two telegrams had been drafted on 12 April, one to the Canadian 
The response from London was prompt and favourable. Canadian High Commissioner Vincent Massey sent three telegrams in reply. The first said that the British authorities were "very much interested and greatly appreciate suggestion contained in your message," but had themselves taken no steps as yet regarding Greenland. The second described the procedure Great Britain had followed in occupying the Faroe Islands on 9 and 10 April. The third described in great detail the reaction of the British authorities, saying that they "have expressed to me officially their great appreciation" of the proposed Canadian action, and "hope we will proceed with any plans that are feasible." However, they asked to be informed in advance of any such steps and wanted to associate themselves with any prior notification to the United States, which should emphasize that any occupation would be temporary and that reimbursement to the mine owners would be made. They did not consider that German seizure of the mines or even a strong attack upon Ivigtut was likely, but deterrent action would be justified. ${ }^{25}$

The response from Washington to the Canadian plan was not nearly as favourable as that from London. The telegram which had been drafted on 12 April asked Christie to inform the US government "confidentially" that the Canadian government was considering sending a small force to Greenland to prevent German occupation, but apparently this telegram was not sent. ${ }^{26}$ However, the news that Canada and Great Britain had been in communication on the subject appeared in press reports on the same day, having been given out by Prime Minister King the preceding day in what must have been a press interview. ${ }^{27}$ Christie saw Cordell Hull, at Hull's request, on 13 April, and was informed that he had already talked to Lord Lothian and the British Ambassador, about Greenland on 12 April. Hull provided both Lord Lothian and Christie with copies of an aide-mémoire which drew attention to the fact that in June 1920 the United States had informed Great Britain that it would not recognize the right of a third government to acquire Greenland if Denmark should desire to dispose of it. The aide-mémoire added that the American position remained unchanged. On Christie's inquiry Hull said that the US had nothing further in contemplation at the moment. Christie felt that "it would seem a reasonable deduction that the United States Government, as at

\footnotetext{
High Commissioner in London and the other to the Canadian Minister in Washington, but it is evident that the one referred to was that to London. It informed Massey that the Canadian Government was contemplating limited action in Greenland and asked him to ascertain the British appreciation of the situation and "any action they have in contemplation in or west of Iceland." Secretary of State for External Affairs to High Commissioner in London, Telegram No. 393, 12 April 1940, RG 25, vol. 2731, file 267-J-40C, vol. 1, LAC.

25 Massey to Secretary of State for External Affairs, Telegram Nos. 441, 445, 447, 13, 15, 15, April 1940, RG 25, vol. 2731, file 267-J-40C, vol. 1, LAC.

26 Secretary of State for External Affairs to Canadian Minister in Washington, draft telegram, 12 April 1940, RG 25, vol. 2731, file 267-J-40C, vol. 1, LAC.

27 Clipping from Montreal Gazette, 12 April 1940, with pencilled comment. American papers (e.g., Daily News, 12 April) spoke openly of the possibility of a Canadian expeditionary force landing in Greenland. RG 25, vol. 2731, file 267-J-40C, vol. 1, LAC.
} 
present advised, regard Greenland as a part of the Western Hemisphere and subject to the Monroe Doctrine, but do not so regard Iceland." 28

On 15 April, a revised and enlarged version of the telegram drafted on 12 April was sent to Christie, requesting that he inform the American authorities of the Canadian government's tentative plans. The new version listed the three major causes of concern from Canada's point of view: (1) the danger of a German foothold being established in Greenland; (2) the danger of a German attack on the mines at Ivigtut; (3) the need to provide for the inhabitants of Greenland. Christie was directed also to find out what truth there was in press reports that the US was considering some kind of action. These reports, if true, would necessitate revision of Canadian plans. ${ }^{29}$ Christie assured the State Department on 16 April that the proposed action was of a temporary nature and that it would not be undertaken without assessing American views. He was told that these views would be given within a few days. ${ }^{30}$ Escott Reid, who accompanied him, got the impression that the Americans were seriously contemplating some action themselves. ${ }^{31}$

On the morning of 16 April, Lord Lothian met with Under Secretary of State Sumner Welles at the State Department, after which the Associated Press reported Lothian to have said that "neither Britain nor Canada would undertake an occupation of Greenland unless absolutely certain that Germany was sending an expeditionary force, which was most unlikely." 32 Lothian allegedly denied any knowledge of reports that Canada might occupy Greenland, but added that "nevertheless if Britain decided that Greenland should be occupied to forestall a German move, the undertaking would be carried out by Canada in order to avoid complications involving the Monroe Doctrine." ${ }^{33}$ Skelton telephoned the Legation in Washington

28 Christie to Secretary of State for External Affairs, No. 716, 13 April 1940; US aide-mémoire, 13 April 1940, RG 25, vol. 2731, file 267-J-40C, vol. 1, LAC, also DCER, 1939-1941, vol. 7, pt. 1, 958-59.

29 Secretary of State for External Affairs to Canadian Minister in Washington, No. 55, 15 April 1940, RG 25, vol. 2731, file 267-J-40C, vol. 1, LAC.

30 Canadian Minister in Washington to Secretary of State for External Affairs, No. 61, 16 April 1940, and aide-mémoire, 16 April 1940, RG 25, vol. 2731, file 267-J-40C, vol. 1, LAC. See aidemémoire also "Canada-Greenland Relations--General File," in RG 25, vol. 3278, file 6732-40, vol. 1 (June 10, 1944-Feb. 12, 1959), LAC.

31 Minute by Escott Reid on conversations at State Department, 16 April 1940 (same date), RG 25, vol. 2731, file 267-J-40C, vol. 1, LAC.

32 Reported by Associated Press, 16 April 1940.

33 New York Times, 17 April 1940; clipping in RG 25, vol. 2731, file 267-J-40C, vol. 1, LAC. On Dr. Skelton's telephoned request for confirmation R.M. Macdonnell of the Canadian Legation in Washington immediately contacted the writer of the Associated Press report, who insisted that Lothian had been correctly quoted. Macdonnell telephoned this back to Skelton the same evening (16 April), and was told that two cabinet ministers whom Skelton had just seen "were in a high state of indignation over the British Embassy's apparent willingness to give commitments on behalf of Canada." Memo by R.M. Macdonnell, 16 April 1940 and Skelton to Ralston, 16 April 1940, RG 25, vol. 2731, file 267-J-40C, vol. 1, LAC. In a letter to King the Secretary to the Cabinet, A.D.P. Heeney, commented: "It does seem strange that one who has had such great opportunities to observe 
the next morning and instructed them to tell the State Department that the Canadian government had not authorized Lothian's press statement and that Canada would take no action until American views were known. ${ }^{34}$ Macdonnell and Reid promptly carried out these instructions, and the Legation reported that Lothian personally denied having made any statement to the press implicating Canada. ${ }^{35}$ A summary of the incident was included in a lengthy cable from the Department of External Affairs to the High Commissioner in London, which complained that the alleged statement had rendered that situation "embarrassing to Canada." 36

On 17 April, after Reid had delivered Skelton's telephoned message at the State Department, John D. Hickenson made some "off-the-record" remarks explaining to Reid in categorical terms that the United States did not want Canada to take the proposed action in Greenland, because "other belligerents would claim that if one belligerent had occupied a part of the western hemisphere, they also had a right to occupy some part of it." ${ }^{37}$ In the context of Japanese Foreign Minister Arita's statement the previous day, asserting that Japan would oppose any change in the status quo of the Dutch East Indies if Germany invaded Holland itself, ${ }^{38}$ Cordell Hull had hastily stated the American view that all interested states should respect the status quo in the Dutch colony and elsewhere as well. ${ }^{39}$ Skelton speculated "that Washington ... might be concerned lest occupation of Greenland left orphaned by the German invasion of Denmark, be held to afford a precedent for occupation by some other country of the Dutch East Indies left orphaned by a German invasion of Holland." 40 His suspicions soon confirmed, ${ }^{41}$ Christie found the "analogy" uncompelling given that Japan was not a belligerent. ${ }^{42}$ The State Department's political relations adviser James C. Dunn, however, insisted that "it would be highly inadvisable for Canada to take proposed action in respect of Greenland" because the Japanese did not need a perfect analogy. The United States wanted to

the growth of the Commonwealth, of recent years, should be guilty of such an obvious impropriety." James Eayrs, In Defence of Canada: Appeasement and Rearmament (Toronto: University of Toronto Press, 1965), 168, citing Heeney to King, 17 April 1940, King Papers. Smith was unable to find this document in the King Papers.

34 Skelton to Ralston, 17 April 1940; Memo by Macdonnell and Reid, 17 April 1940, RG 25, vol. 2731, file 267-J-40C, vol. 1, LAC.

35 Canadian Minister to External Affairs, No. 62, 17 April 1940, RG 25, vol. 2731, file 267-J-40C, vol. 1, LAC.

36 External Affairs to High Commissioner in London, No. 413, 17 April 1940, RG 25, vol. 2731, file 267-J-40C, vol. 1, LAC.

37 Secret and personal memo by Reid for Christie, 17 April 1940, RG 25, vol. 2731, file 267-J-40C, vol. 1, LAC.

38 Clipping from New York Times, 17 April 1940, RG 25, vol. 2731, file 267-J-40C, vol. 1, LAC.

39 Clipping and verbatim text of Hull's statement from New York Times, 18 April 1940, RG 25, vol. 2731, file 267-J-40C, vol. 1, LAC.

40 Skelton to King, 18 April 1940, DCER, 1939-1941, vol. 7, pt. 1, 966.

41 Skelton to King, 18 April 1940, DCER, 1939-1941, vol. 7, pt. 1, 966; see also Minute by "H.A.," 18 April 1940, RG 25, vol. 2731, file 267-J-40C, vol. 1, LAC.

42 Memo by Skelton, 19 April 1940, RG 25, vol. 2731, file 267-J-40C, vol. 1, LAC. 
base its actions respecting Greenland on solely humanitarian considerations for as long as possible. ${ }^{43}$ Christie informed Skelton by telephone that Dunn's reply was sound and provided a basis for "playing along," with Skelton advising that King harboured more doubts than others in Ottawa about the advisability of extensive action. $^{44}$

From this moment, there could be no doubt in Ottawa of the official American view of Canadian plans. Nevertheless, preparations to dispatch Force " $\mathrm{X}$ " (the name given to the Greenland expedition), which had begun as soon as the joint planning subcommittee's paper had been signed by the Chiefs of Staff, continued. On 15 April, a General Staff Instruction (No. 1) stated that authorization of the expedition by the Canadian government was expected within two or three days, and gave details regarding personnel, equipment, and responsibilities. It specified that the advance party would proceed to Greenland in N.B. McLean about two weeks after the expedition had been authorized, and that the main body would follow during the first week in June. ${ }^{45}$ A second General Staff instruction on 16 April gave word that the Minister of Transport (C.D. Howe) had ordered N.B. McLean to sail to Quebec without delay. ${ }^{46} \mathrm{~A}$ third instruction, also on the same day, directed that the advance party be made ready immediately, even though dispatch of the force had not yet been officially authorized..$^{47}$ Another, on 17 April, said that N.B. McLean would arrive at Quebec on 20 April, and therefore all arrangements for the dispatch of the advance party were to be completed by 4 May. $^{48}$ (This instruction had to be countermanded by a later one dated 26 April, which said that the ship would not be ready before 15 May and therefore all other arrangements should be completed by 11 May. ${ }^{49}$ ) These arrangements, even for such a small operation, were necessarily quite involved and extensive, not only because the expedition was to be sent as soon as possible but also because it would have to be almost completely self-contained; and there was a whirlwind of activity getting everything ready. ${ }^{50}$

43 Christie to Secretary of State for External Affairs, No. 65, 19 April 1940, RG 25, vol. 2731, file 267-J-40C, vol. 1, LAC.

44 Memo by Skelton, 19 April 1940, RG 25, vol. 2731, file 267-J-40C, vol. 1, LAC. On the events during the week ending April 19, see Langer and Gleason, Challenge to Isolation, 430-31.

45 RG 25, file 8559, microfilm reel no. C-8365, LAC; also "Occupation and Defence of Ivigtut, Greenland," Gen. Staff Instruction No. 1, 15 April 1940, file 114.1 (D 90), Directorate of History and Heritage (DHH).

46 Gen. Staff Instruction No. 2, 16 April 1940, file 114.1 (D 90), DHH.

47 Gen. Staff Instruction No. 3, 16 April 1940, file 114.1 (D 90), DHH.

48 Gen. Staff Instruction No. 7, 17 April 1940, file 114.1 (D 90), DHH.

49 Gen. Staff Instruction No. 10, 26 April 1940, file 114.1 (D 90), DHH.

50 Lt. Col. J.P. Girvan of the 48th Highlanders was selected as commanding officer of the Ivigtut force on 18 April and instructions were drafted the same day which gave him the dual responsibility of defending the locality and maintaining correct and cordial relations with the local population. C.G.S. Anderson to Minister, 18 April 1940; C.G.S. to Lt. Col. Commanding Ivigtut Force, 18 April 1940; C.G.S. to A.G., 22 April 1940, RG 25, file 8559, microfilm reel no. C-8365, LAC. See also 
On 20 April, in a telephone conversation with Christie, Skelton opined that Canada would not be satisfied to leave safeguarding the cryolite mine and the Greenland coast unsettled and would resent it if anyone else assumed these responsibilities. A day later he phoned again, having talked the matter over with Ralston, and said that the government did not want to go ahead with further preparations, which would be somewhat costly, unless they could do so without causing difficulties. In a further conversation on 22 April, Christie advised securing in advance the consent of local authorities in Greenland, a point which Skelton said he appreciated. ${ }^{51}$ A cable from the Acting Secretary of State for External Affairs

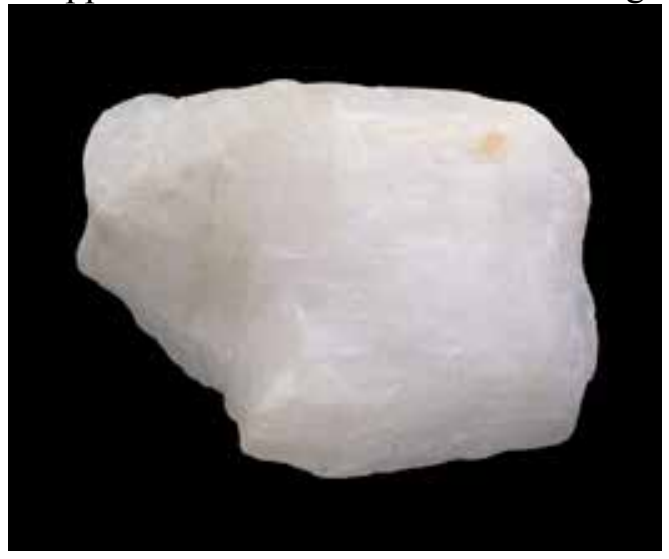

Ivigtut Cryolite deposit, Ivittuut (Ivigtut), Greenland. (Wikimedia Commons) (Ralston) to Massey in London on 21 April said that the government was considering "whether it would be desirable to suspend present plans involving military action," 52 and a telegram to Christie on 23 April said that while the matter was being reexamined "no action will be taken." 53 On 27 April Skelton wrote a note to Christie saying that his suggestion for the Prime Minister's consideration would be: "We have been assuming that preventive military action at present is out of the question." 54 It is evident that a retreat had begun.

The touchiest matter to handle was the question of the cryolite. The mines were owned by a Danish company, with the Danish government possessing 50\% of the stock, and the company headquarters was in Copenhagen. The German occupation placed upon the local authorities in Greenland the responsibility of taking control of the mines and their operations. ${ }^{55}$ This was a monopoly ownership and the crude cryolite was shipped to only two customers, the Danish refining company involved and an American company, the latter of which turned over a small proportion of the ore to a Canadian company. In 1939 about 41,000 tons

Maurice Pope's account of the affair in his Soldiers and Politicians (Toronto: University of Toronto Press, 1962), 144-45.

51 Minutes by Christie, 20, 21, 22 April 1940, RG 25, vol. 2731, file 267-J-40C, vol. 1, LAC.

52 Acting Secretary of State for External Affairs to High Commissioner in London, No. 438, 21 April 1940, RG 25, vol. 2731, file 267-J-40C, vol. 1, LAC.

53 Acting SSEA to Canadian Minister in Washington, No. 60, 23 April 1940, RG 25, vol. 2731, file 267-J-40C, vol. 1, LAC. See also Memo by Skelton, 24 April 1940: “ “.. it is, therefore, not our intention to take any present preventive military action.” RG 25, vol. 2731, file 267-J-40C, vol. 1, LAC.

54 Skelton to Christie, 27 April 1940, RG 25, vol. 2731, file 267-J-40C, vol. 1, LAC.

55 Christie to Skelton, 29 April 1940, reporting information obtained from Kauffmann, RG 25, vol. 2731, file 267-J-40C, vol. 1, LAC. 
were sent to Denmark and about 15,500 tons to the US, of which about 2,900 tons were destined for Canada. ${ }^{56}$ The American company was the Pennsylvania Salt Manufacturing Co. of Philadelphia; the Canadian was the Aluminum Company of Canada Ltd. at Arvida, Quebec. As noted above, the Canadian company began making strong representations to the Canadian government as soon as Denmark was under occupation, ${ }^{57}$ while Penn. Salt did likewise in the United States. ${ }^{58}$

Christie was instructed on 15 April to inform the State Department that Canada was considering temporary, emergency defensive action which would make the country, for the duration of the war, a sort of "trustee" for the Danish government in Greenland. ${ }^{59} \mathrm{He}$ emphasized that Canada "intended to make cryolite available not only to consumers in Canada and the United Kingdom, but also to consumers in the United States." ${ }^{60}$ Penn. Salt would unlikely have been satisfied with this generosity; in any case, this company was making its own efforts to secure its desired supply of the ore. It sent a wireless message to the government controller of the cryolite mines at Ivigtut on 18 April, via Louisburg, inquiring about the safety of production and supply. The controller sent a reply the same day saying that the governorship might have to take over the mines. Leonard Beale of Penn. Salt sent another message the same day asking when the first ships could be loaded and saying he was working closely with the Danish minister Kauffmann. Several such messages were sent back and forth during the following days, ${ }^{61}$ which Canadian government censors intercepted in Nova Scotia before they were sent on to their destination. ${ }^{62}$ Whether the two sets of circumstances were related is unclear, but

56 Christie to SSEA, Apr. 20, 1940, enclosing statements obtained from the US Department of Commerce, RG 25, vol. 2731, file 267-J-40C, vol. 1, LAC.

57 Skelton to Acting Deputy Minister Naval and Air Services, DND, 11 April 1940, RG 25, file 8559, microfilm reel no. C-8365, LAC.

58 Canadian Minister to SSEA, 16 April 1940, reporting conversation at State Department, 16 April, RG 25, vol. 2731, file 267-J-40C, vol. 1, LAC.

59 SSEA to Canadian Minister in Washington, No. 55, 15 April 1940, RG 25, vol. 2731, file 267-J-40C, vol. 1, LAC.

60 Canadian Legation to External, paraphrase of No. 61 initialed E.R. (Escott Reid), 16 April 1940, RG 25, vol. 2731, file 267-J-40C, vol. 1, LAC.

61 It is not clear to me whether they were all wireless messages; they are variously spoken of as messages by wireless, radio, telegraph, and telegram. See RG 25, vol. 2731, file 267-J-40C, vol. 1, LAC for copies of these messages.

62 The messages were also being intercepted in Montreal. See Lt. Col. Murray to Keenleyside, 21 and 22 April 1940, RG 25, vol. 2731, file 267-J-40C, vol. 1, LAC. See also Under Secretary of State for External Affairs to Acting Deputy Minister DND (Militia), letter drafted by J.E. Read (19 April 1940), RG 25, vol. 2731, file 267-J-40C, vol. 1, LAC asking that "any further communications between the Danish Legation at Washington and Greenland should be stopped, and only forwarded after approval from this Department," and that the same should be done with communications "between United States interests and the Kryolite [sic] Mines." And see memo by Skelton (24 April 1940), saying that the telegrams "from him [i.e. the Danish Minister] and from Penn-Salt have been intercepted by our cable censor and in all cases have been sent on after being translated and examined." On 24 April the Chief Telegraph Censor of DND informed Keenleyside that messages 
Dunn reassured Christie on 19 April that, because the US was the largest consumer of cryolite, Canada could rest assured that the Americans would protect the source of supply. ${ }^{63}$

Minister of Finance Ralston, who also had strong views about the cryolite supply, complained in a telegram to High Commissioner Massey on 21 April that some "private interests in United States, with cooperation of Danish representatives there, are apparently considering seeking control of cryolite production." ${ }^{64}$ Keenleyside also observed on 30 April that the Penn. Salt Co. "is seeking according to certain reports, to obtain practically the whole output for present year." 65 For the Aluminum Company of Canada, the proper course of action was straightforward and clear. Asserting that the newly appointed AmericanDanish Greenland Commission ${ }^{66}$ could not possibly give the needed protection, F.W. Bruce of the company stated forthrightly in a letter to Keenleyside on 27 April that "the only way in which these interests can be properly protected is to have the Canadian Government occupy and control the output of the mine." He urged that this protection be provided by either Canadian or Allied forces, or, as an obviously poor alternative, that Canada have representation on the AmericanDanish Greenland Commission. ${ }^{67}$ In time Canada, at least officially, seems to have become reconciled to the idea of American protection of the cryolite, but at this stage retained a strong feeling that the job of protection, and also a prior claim on the ore, were rightly Canada's own. It is also apparent that Danish and Greenland officials in North America were more inclined to seek American protection than Canadian. However, Kauffmann assured Christie repeatedly in an interview on 26 April that "his full desire in all this matter" was "to act to the satisfaction of the Canadian and British Governments," and that he would do his best to see that the supplies of cryolite to Canada were continued..$^{68}$

were no longer passing through the wireless station at Louisburg, but MacKay Radio of Brentwood, N.J. was now communicating with Julianehaab. Lt. Col. Murray to Keenleyside, 24 April 1940, RG 25, vol. 2731, file 267-J-40C, vol. 1, LAC. See also copy of excerpt from "Telecommunication Reports," Washington, DC (20 April 1940), RG 25, vol. 2731, file 267-J-40C, vol. 1, LAC.

63 Christie to SSEA, No. 65, 19 April 1940, RG 25, vol. 2731, file 267-J-40C, vol. 1, LAC.

64 Acting Secretary of State for External Affairs to High Commissioner for Canada in London, No. 438, 21 April 1940; and Ralston to Christie, 23 April 1940, RG 25, vol. 2731, file 267-J-40C, vol. 1, LAC.

65 Memo drafted by Keenleyside for Skelton, 30 April 1940, RG 25, vol. 2731, file 267-J-40C, vol. 1, LAC.

66 The commission consisted of Hans Christian Sonne, New York (Chairman); Dr. Paul Bentzen, Roosevelt Hospital (N.Y.); Ruth Rhode, former American Minister to Denmark; John Dynely Prince, Columbia University Professor and former American Minister to Denmark; Dr. Henry G. Leach, President, American-Scandinavia Foundation; Dr. Isaiah Bowman President, Johns Hopkins University; Leonard J. Beale, President, Penn. Salt Mfg'ing Co.; and Captain Bob Bartlett, explorer now based in New York. Statement for press by Kauffmann, Apr. 26, 1940, RG 25, vol. 2731, file 267-J-40C, vol. 1, LAC.

67 Bruce to Keenleyside, 27 April 1940, RG 25, vol. 2731, file 267-J-40C, vol. 1, LAC.

68 Christie to SSEA, 26 April 1940, RG 25, vol. 2731, file 267-J-40C, vol. 1, LAC. It is interesting 
Prime Minister King returned from his visit to the United States on 1 May. $\mathrm{He}$ had visited President Roosevelt at Warm Springs, Georgia, on 23 and 24 April, and he recorded their discussion about Greenland as follows:

He showed me the letter from Mr. Hull to himself, which was along lines already reported by Christie to me. The Americans were anxious that Canada should not undertake anything in particular. I told the President we had received from the owners of the cryolite mines requests to protect them and had undertaken in correspondence with Britain to see that men were supplied who could be of service about the mine in protective ways. That we would expect, however, the British fleet to do what was needed on the Atlantic; also that we had sent up each year a ship to Baffinland which brought supplies to Greenland. That this ship would be taking more in the way of supplies this year than previously.

The President said he would send a Revenue Cutter, also men with a number of radio instruments to be distributed at different points along the coasts so that communication could be had from one part to another very rapidly. He thought that the captain of the Revenue Cutter should meet with the master of our ship before the two of them started out and have an understanding between them as to the best way of proceeding.

The United States would help under the Red Cross in the matter of supplies; also would help to supply radios, binoculars, etc. That if a real danger arose he would have to leave it to the British to deal with submarines, etc. at sea. He thought no effort should be made, either by the United States or Canada to get possession of Greenland, that whatever was done should be done subject to Greenland managing her own affairs. ${ }^{69}$

to reflect that although the major preoccupation was with the defence of Ivigtut, there was also the question of the defence of Arvida. This was not entirely overlooked; e.g., see "C.S.C. Misc. Memoranda Aug. 40 - Aug. 41, "vol. 1, file 193.009 (D2), DHH for a memo on the subject written by the Chiefs of Staff to their Ministers on March 3, 1941: “....The aircraft manufacturing industry of the British Empire is now about $90 \%$ dependent on this Plant for the supply of aluminium ingots. The only other smelter in the Empire is in Scotland, and this has already been bombed.... The vulnerability of this industry is extreme.... A modern aeroplane is capable of flying from occupied France to Arvida, a distance of 3,000 miles, with a 5,000 lb. load of bombs, and returning to France...."

69 King Diaries, no. 147, 402, LAC. I have not seen any evidence which would warrant King's statement that requests had been received from the owners of the cryolite mines for Canadian protection. Considering the rumpus he raised afterwards with members of his official circle over the matter, it is difficult to understand what he meant when he said that men would be supplied "who could be of service about the mine in protective ways," since they could hardly give meaningful protection unless they were equipped with weapons. It would appear that King himself, at least during these early stages, was very uncertain about what action should be taken. His attitude, not entirely untypical of him, might be summarized thus: "Protection if necessary, but not necessarily protection." See Langer and Gleason, Challenge to Isolation, 433, for the following statement: "Though Mr. Roosevelt had been carefully briefed on the American desire to avoid Canadian intervention in Greenland, his response led Mr. Mackenzie King to conclude that the President expected the British Navy to repel any Nazi attack." 
On his return trip to Ottawa, King spent 27-29 April in Washington where he talked with several people, including Loring Christie. "Spent some time with Christie going over questions likely to come up for discussion including the Greenland matter," King recorded:

I was astonished to find that he had been given instructions to say that Canada would prepare a defence force for Greenland. I had objected to this to S. over the phone before leaving and thought his cable to England did not go that far. Apparently Ralston being concerned about Aluminum and S. zealous to have Canada rather than England handle Greenland matters on North American basis, had between them gone farther than I think was wise. I thought the position taken by the Americans was wise. Christie agreed that the matter has now been satisfactorily straightened out. Clearly our people had been a little over-zealous in preparing for a little war on Canada's own account. ${ }^{70}$

King's version of the matter was unfair to others. He knew what was in the cable to England and had initialled the final draft himself; he himself had given out the news that Great Britain and Canada were in communication about Greenland; Christie had been instructed specifically to say only that Canada was considering sending a small force to Greenland; Christie had already told King by phone on 22 April of the American statement on 19 April; and Skelton had informed Christie on 21 and 23 April that the matter was being re-examined and for the present no action would be taken.

While in Washington, King met with Cordell Hull twice; on advice from Roosevelt he talked with Norman Davis, President of the Red Cross; and he saw Roosevelt again at the White House for a few minutes just before leaving. With each person he raised the question of what the American reaction would be if nothing were done to protect Greenland and a sudden German attack occurred. Hull, who was obviously concerned about what Japan might do, said that such a German attack would raise the question of the applicability of the Monroe Doctrine. Roosevelt did not think a German attack probable but if it happened the Allied naval forces would have to take action. Davis, who was resolutely antiAxis, said that he thought the US Navy would sail in and "blow them [the German raiders] out of existence." King brought to his attention the difference between his view and the President's, stressing repeatedly that Canada had not had in mind preventive military occupation or political control, and told Davis that when he left Ottawa "the thought was to see what the Defence Department might do, but not to take any final steps." He and the Americans agreed that continuing consultation between Canada and the United States was necessary, and that whatever they might do respecting Greenland should be on parallel lines. ${ }^{71}$

Upon arriving in Ottawa King talked with several Cabinet ministers, and then

70 King Diaries, no. 147, 425, LAC.

71 King Diaries, no. 147, 426-40, LAC; Memo by Skelton, 2 May 1940, initialled by King, King Papers, vol. 394, no. 47, C 277342-5, LAC. 
visited Ernest Lapointe, who was in the General Hospital. "I told him of my talk with Ralston," King recorded in his diary. "He entirely agreed about the Greenland situation, saying that he himself felt that Ralston and Power had gone too far." 72 At a Cabinet meeting the next day Greenland was one of the subjects discussed. King noted:

Found to my amazement that between them Ralston and Power had already a military expedition fitted out to go to Greenland which included guns for mounting, soldiers, some naval defence etc. Power asked if they should be demobilized and I said certainly and at once. Ralston seemed a bit tenacious about our having been asked by England to look after the property and what it might mean to have bombs destroy the cryolite mines. It seemed impossible to bring home the pictures of what the United States was doing to keep the Pacific quiet as against Japan. With no British fleet and the unwisdom in consequence of giving and [sic] excuse to the Japanese for adopting toward the Dutch East Indies the kind of protection that Canada would have been exercising over Greenland. It is just matters of this kind which make me feel the importance of not going abroad if that can be avoided. ${ }^{73}$

Here again, King's version does not quite accord with fact and gives rather exaggerated impressions. In a letter of 27 April to Christie, for example, Skelton had written: "I am inclined to suggest for the Prime Minister's consideration; 1. As regards action by Canada-(a) We have been assuming that preventive military action at present is out of the question." "74 Christie received the letter on 29 April and gave a copy of it to King who "indicated that he would take the points up" with Skelton in Ottawa." 75 Thus he had another categorical statement that military action was not contemplated for the time being, and the expedition - although being made ready in case the decision was taken to use it - was by no means completely fitted out.

In the same letter Skelton had written: "As regards the United States, Colonel Ralston has wished to defer a reply till we hear from London. We have sent two telegrams without any response and on Thursday telegraphed asking for a reply." In this connection the time element is of some interest. The Cabinet meeting on 2 May was held between 3:15 p.m. and 7:30 p.m., ${ }^{76}$ and before 5:15 p.m. the Chiefs of Staff were instructed "that 'Force X' is to be demobilized and all action in connection with it suspended."77 Massey's cable (No. 527) reporting Eden's response was received in Ottawa the same evening at 7:30 p.m., just as the meeting

\footnotetext{
72 King Diaries, no. 147, 447, LAC.

73 King Diaries, 1 May 1940, no. 448, LAC.

74 Skelton to Christie, 27 April 1940, RG 25, vol. 2731, file 267-J-40C, vol. 1, LAC.

75 Christie to Skelton, 1 May 1940, RG 25, vol. 2731, file 267-J-40C, vol. 1, LAC.

76 King Diaries, no. 147, 448, LAC.

77 Col. Clyde R. Scott (Military Secretary) to CGS, CNS, and CAS, 2 May 1940, RG 25, file 8559, microfilm reel no. C-8365, LAC.
} 
ended. ${ }^{78}$ Thus the meeting was conducted without knowledge of the contents of the cable, and neither Ralston, nor King, nor anyone else present was aware of the persistence with which the British government was clinging to its opinion that Canada should immediately send an expedition to protect the cryolite mines.

On 6 May, Keenleyside and Skelton wrote a long memo for the Prime Minister entitled "Proposals for a Canadian Policy Relating to Greenland" in which they summarized the complicated situation which had arisen and emphasized that, as things stood Canada found herself in the unhappy position where she would seriously offend the United States by action and Great Britain by inaction. Noting that the "simple solution" of the N.B. McLean expedition had met with American objections, King pencilled in the margins that "this would give rise to a very serious problem." The US had made no proposals itself, and that "the assurances so far given by the United States are practically valueless as it would probably take a German raider or submarine less than an hour to put the mine more or less permanently out of operation." They then put forward alternative or corollary suggestions, with King pencilling his own comments in the margin:

1. Canada could send a reassuring telegram to Greenland, offering help and inviting suggestions. (King agreed.).

2. The H.B.C. ship Nascopie should be sent quickly to Greenland to take supplies and bring back ore. (King agreed.).

3. The N.B. McLean expedition should be kept in partial readiness. (King was unwilling).

4. Canada should send a consul to Greenland on the Nascopie (King agreed.).

5. Canada should emphasize to Great Britain that whether American views and arguments respecting Greenland and Japan were valid or not it would be a great mistake to disregard them, and that she was attempting to bring home to the United States the vulnerability of the cryolite mine. She should ask the U.K. to detain at Kirkwall (in the Orkneys) the Danish ship Julius Thomsen, which had been dispatched to Greenland before the German invasion, until after the Nascopie had arrived in Greenland. (King agreed, but rejected other suggestions that Canada should inform the U.K. that the N.B. McLean would be kept available, and ask her urgently not to send British warships to Ivigtut as indirectly suggested in a cable from Massey (No. 536) on 3 May.)

6. Canada should inform the US that she was still apprehensive about the safety of the cryolite mine and would like some more specific assurance about it, and should tell her also about the plans for the Nascopie and the Canadian Consul. A discussion might also be initiated about the cryolite, involving Penn Salt, the Aluminum Co. of Canada, and perhaps also Kauffmann. (King agreed, but indicated that 


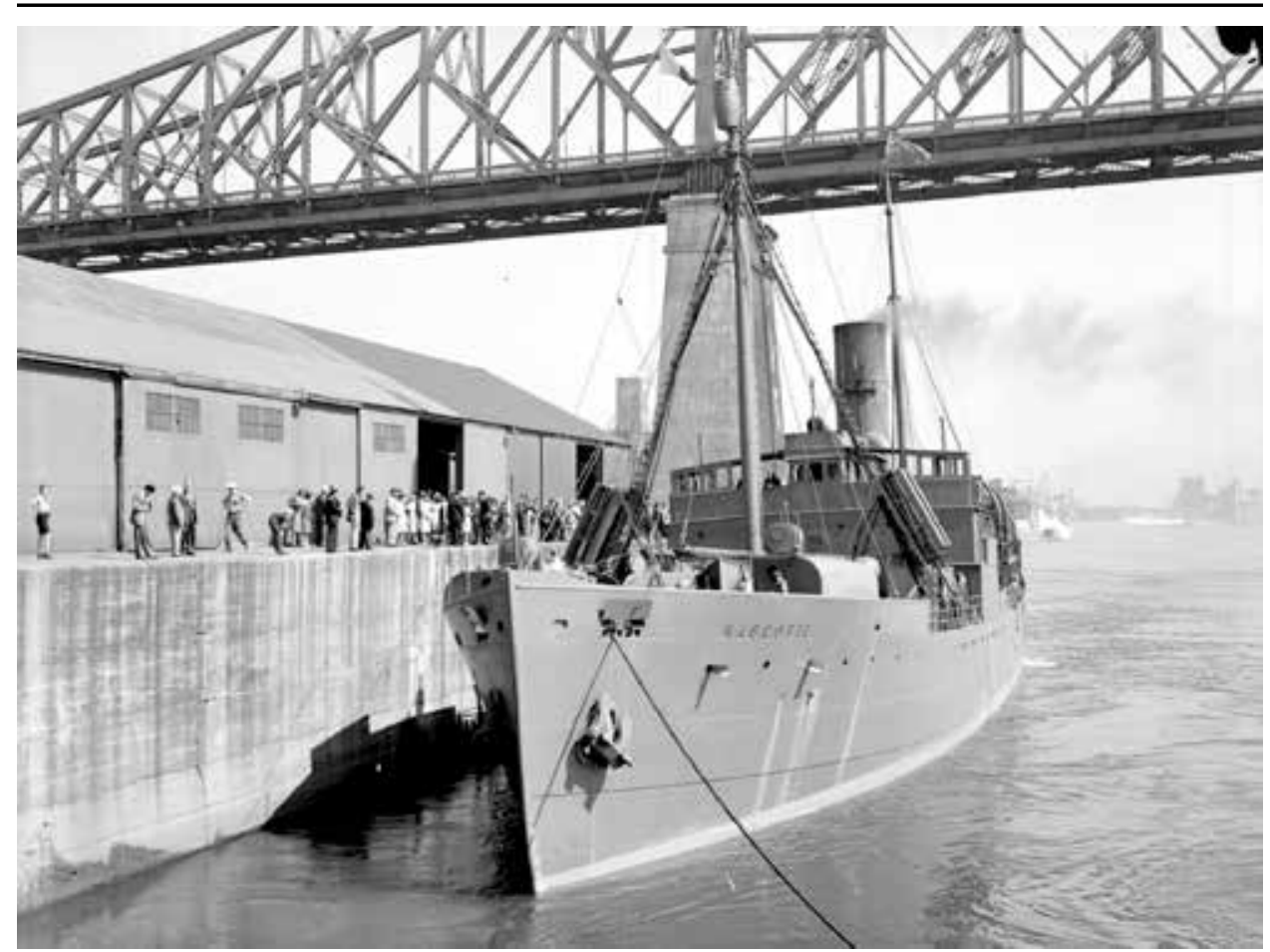

Photo of Nascopie. (Wikimedia Commons)

he was less fearful than the writers about a sudden German raid which would destroy the mine. $)^{79}$

It would appear that this memo provided the basis for the Canadian government's policy and action respecting Greenland over the next few weeks. The concept of military intervention died hard in some quarters, however, if one can judge from King's diary entries, while other Cabinet members either continued to promote the idea or else revived it. In the light of what had already happened it would seem a fair assumption that they had agreed to postpone plans for action until King's return from the United States, and then were voicing their real convictions when they advocated for some sort of military expedition. The diary entries tell the story from King's own point of view:

May $8 \ldots$ I took a short rest and then returned to the office to go over Greenland situation with Skelton. In my absence Ralston and Power had organized a military expedition for Greenland and had advised the British they were so doing. The British had come back urging that the expedition be carried out and showing no sympathy with the American point of view.

79 Memo by Skelton for PM, and Memo by Skelton and Keenleyside, "Proposals for a Canadian Policy Relating to Greenland," 6 May 1940, King Papers, vol. 394, no. 47, C 277352-59, LAC. Keenleyside had already written a somewhat similar memo on April 30, and in this and other documents gives the impression that he was one of the "hawks" regarding action by Canada in Greenland. See also Massey’s cable No. 536, 3 May 1940, at C 277351. 
I had to be firm about not antagonizing a great nation who is watching the critical situation on the Pacific, by attempting a violation which would be worse than that of the British landing in Norway. This time it is the Maritime Provinces outlook on an industry which is managed by someone from that province $[\mathrm{sic}]$. This little circumstance blinding the eyes of men to the larger world situation. We are put into the difficult cleft-stick position now through having [word or words missing] from the British or American side. I shall have to carry the blame if any difficulty should arise.....

May 9 ... Took up the Greenland situation anew. Read later dispatch sent to Washington. Mackenzie joined with Ralston in favouring our going ahead with and [sic] expedition to Greenland whether viewed with favour by the United States or not. I pointed out that an expedition of the kind if there were a German attack, would only receive the fate that the British had in Norway, in which event we would be blamed for sending inadequate [sic] forces (though not able to send anything else). On the other hand if an expedition were sent, whether a German raid occurred [sic] or not, the United States would be terribly offended and relations between the United States, England and Canada strained, at a moment when there is the utmost need for keeping them as cordial as possible. I read to Council a dispatch being sent to Christie pointing out the danger of leaving the cryolite mines unguarded which was approved by Council. I asked Lapointe to prepare as soon as possible another message for the British.....

May 14 ... I read to Council a telegram prepared by Skelton re sending of the "Nascopie" to Greenland.

I felt that both Ralston and Power were not seeking to be particularly helpful by bringing up again the question of the military expedition, Ralston indicating that we were doing all Britain had asked, and Power coming back to the desirability of sending representatives of the army, navy and air.

Crerar did not have a knowledge of what his own department had done. Could explain nothing to Council. Neither had Power, Gardiner and Crerer [sic] secured anyone as Consul General, which I had requested at a previous meeting. I felt a little nettled and made it clear that we had previously settled the policy of the Government, which was that our action was to parallel that of the US, and that I would not re-open the question of any expedition. ${ }^{80}$

The matter was brought up at a meeting of the Cabinet War Committee on 10 May, but the minutes say little more than that the composition of the Nascopie party, and what it should do, were "discussed." 81

80 King Diaries, no. 147, 461, May 8; 465, May 9; 485, May 14, 1940, LAC. See also Eayrs, In Defence of Canada: Appeasement and Rearmament, 170.

81 Minutes of the Cabinet War Committee, Meeting No. 3, May 10, 1940, 4, Item 6, LAC. 
It thus seems evident that King had practically dictated to the recalcitrant members of the Cabinet that any Canadian action respecting Greenland must parallel that of the United States. The difficulty at this stage was that there was not much American action that Canada could parallel. Although the US government denied any involvement in the appointment of the American-Danish Greenland Commission, it raised no objections to it. On 1 May, the State Department announced the opening of a US Consulate at Godthaab, naming James K. Penfield of the Far Eastern Division as consul and George L. West Jr., who had been attending the Department's Foreign Service School, as vice consul. ${ }^{82}$ Whether the Greenland authorities or the US government took the initiative in arranging for this move seems a bit uncertain ${ }^{83}$ but the United Greenland Council's resolution adopted at Godhavn on 3 May 1940 expressed that:

in these circumstances it has made us extremely happy to learn of the sympathy expressed officially and unofficially by the Government and the people of the United States, a sympathy which has found its latest expression in the establishment of an American Consulate in Greenland and the dispatch of US Coast Guard Cutters to visit Greenland. It is our hope that, for as long as we remain cut off from our mother country, the United States Government will continue to hold in mind the exposed position of the Danish flag in Greenland, of the native Greenland and

Danish population, and of established public order. ${ }^{84}$

Clearly the Greenland officials wanted American protection. It soon would become equally clear that they did not want Canadian protection. The announcement said also that Penfield would sail on the US Coast Guard cutter Comanche on 10 May, and that arrangements were being made for the US to aid Greenland with foodstuffs and other goods.

Comanche, a small 1000-ton oil-burning vessel armed with two 3-inch guns and two 6-pounders, set sail for Greenland as planned, with Penfield and West aboard. Also aboard was Maurice R. Ready, assistant director of disaster relief for the American Red Cross, who at President Roosevelt's behest was to study the question of material help for the people of Greenland. ${ }^{85}$ Plans were made to

82 Copy of Department of State press bulletin, No. 200, 1 May 1940; New York Times clipping, 2 May 1940, RG 25, vol. 2731, file 267-J-40C, vol. 1, LAC. See also The Polar Times, no. 11 (Dec. 1940): 2; and for Penfield's own account of his first days in Greenland, see RG 25, vol. 2731, file 267-J-40C, vol. 1, no. 12, June 1941, 18-19, LAC.

83 On 26 April Kauffmann told Christie in confidence that he was going to suggest the opening of a consulate to the State Department; on 27 April Berle told Christie that his government proposed sending a consul to Greenland, with Kauffmann's concurrence; on 1 May Berle told Christie that the State Department had heard through Kauffmann that the Greenland authorities wanted the appointment. See RG 25, vol. 2731, file 267-J-40C, LAC.

84 Department of State press bulletin, No. 200, 1 May 1940; and copy of United Greenland Council resolution, 3 May 1940, RG 25, vol. 2731, file 267-J-40C, vol. 1, LAC.

85 Christie to SSEA, No. 80, 9 May 1940; clippings from Washington Star, 8 May 1940, and New York Times, 11 May 1940, RG 25, vol. 2731, file 267-J-40C, vol. 1, LAC. 
send another, larger Coast Guard cutter, Campbell, to Greenland on 1 June, and, after efforts to get her away earlier had failed, she duly sailed on or about the appointed date. ${ }^{86}$ On 15 May, Hugh Cumming of the State Department told Escott Reid that Campbell would be armed with two 5-inch guns, three 3-inch guns, and four machine guns. ${ }^{87}$ On 25 May, however, the New York Herald-Tribune reported that she would be carrying three additional 5-inch and nine additional 3-inch guns, as well as twenty-five machine guns and an anti-aircraft battery. ${ }^{88}$ On 29 May, Cumming told M.M. Mahoney of the Canadian Legation that this information was entirely incorrect and that the ship's armaments were as he had given them on

United States Coast Guard Cutter Comanche. (Wikimedia Commons)

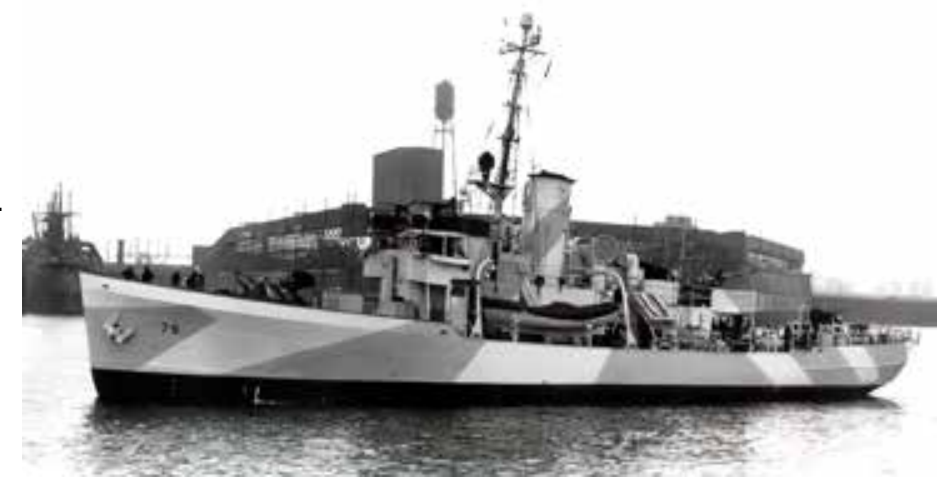

15 May. ${ }^{89}$ In any case the evidence suggests that the American authorities were coming around to the view that somewhat stronger measures were needed in the protection of Greenland.

Against this backdrop of limited but increasing US commitment, the Canadian government endeavoured to take steps to appeal to the American Minister at Copenhagen before the news got to Washington and instructions were sent telling him not to grant any visas. Press reports appearing in American newspapers on 3 May, which said that the government of Nazi-controlled Denmark was planning to send a special commission or delegation to the United States to take care of Danish interests in Greenland, did not ease Canadian worries. The State Department denied categorically any knowledge of such a move and dismissed it as a German "feeler." ${ }^{90}$ However, the members of this commission were appointed and granted visas by the American Minister at Copenhagen before the news got to Washington

86 Christie to SSEA, No. 82, 10 May 1940; vol. 2, clipping from New York Herald-Tribune, 25 May 1940; Minute by Escott Reid, 30 May 1940; Canadian Legation to External, No. 99, 28 May 1940, RG 25, vol. 2731, file 267-J-40C, vol. 1, LAC.

87 Minute by Reid, 15 May 1940, RG 25, vol. 2731, file 267-J-40C, vol. 1, LAC.

88 Clipping from New York Herald-Tribune, 25 May 1940, RG 25, vol. 2731, file 267-J-40C, vol. 2 , LAC.

89 Mahoney to SSEA, No. 1053, 29 May 1940, RG 25, vol. 2731, file 267-J-40C, vol. 1, LAC.

90 Clippings from Washington Times-Herald and New York Herald-Tribune, 3 May 1940; Minute by Escott Reid, 3 May 1940; Canadian Minister to SSEA, No. 76, 3 May 1940, RG 25, vol. 2731, file 267-J-40C, vol. 1, LAC. 
and instructions sent telling him not to grant any visas. At the request of the State Department, the Danish Foreign Minister recalled the commission from Genoa, their embarkation point, before their ship sailed. ${ }^{91}$

Ottawa sent several requests to its legation in Washington during the early part of May asking for information about American plans. Would Comanche be armed? How would the United States handle the appointment of the Greenland consul $?^{92}$ In a telephone conversation on 8 May, Keenleyside told Reid that Ottawa was not satisfied with the State Department's response to Canada's proposed actions because it did not assure adequate protection for the cryolite, and Canadian government officials were put in "a very difficult position" by American and British attitudes. ${ }^{93}$

Reid spoke directly with Hugh Cumming of the State Department on 8 May, informing him that the Canadian government was sending Nascopie to Greenland (but not immediately). Reid suggested fulfilling a proposal by President and Prime Minister for a get-together of Comanche and Nascopie by arranging a meeting in a Canadian port, since Comanche would be sailing first, but Cumming replied that the Comanche's itinerary called only for a stop at St. John's, Newfoundland (then an independent dominion). He informed Reid that Penfield would be taking up his post as consul with merely provisional rather than formal recognition and indicated that there would be no objections if Canada similarly appointed a representative. ${ }^{94}$

The Canadian government did not reply to the official American response to Canada's early plans until 9 May. Phrased in careful language, it acknowledged American concerns that action in the North Atlantic could provide an excuse for Japanese intervention in Southeast Asia, so Canada decided not to send a defensive force to Greenland "at present." Nevertheless, it pointed out that the US had proposed no alternative measure for preventing destruction of the vulnerable cryolite mine, and that the British government deemed it unwise to leave the mine exposed to German attack. The Canadian message noted the anticipated voyage of Nascopie and the possible appointment of a Canadian consul to Greenland, and respecting the cryolite suggested that equitable arrangements be made for production, transportation, and purchase of the ore. ${ }^{95}$ Another telegram of the same date asked Christie for his opinion about the likely reaction of the American government and also of the Danish Minister to a suggestion that the local Greenland authorities mount and man a gun, to be obtained in the US or Canada, for protection of Ivigtut harbour. ${ }^{96}$

91 Mahoney to SSEA, No. 918, 14 May 1940, RG 25, vol. 2731, file 267-J-40C, vol. 1, LAC.

92 Keenleyside to Christie, 6 May 1940, RG 25, vol. 2731, file 267-J-40C, vol. 1, LAC.

93 Memo by Reid for Christie, 8 May 1940, RG 25, vol. 2731, file 267-J-40C, vol. 1, LAC.

94 Canadian Legation to External Affairs, No. 78, 8 May 1940; Minute by Reid, 8 May 1940; Canadian Minister to SSEA, No. 79, 8 May 1940; further minute by Reid, 8 May 1940; Christie to Skelton, 8 May 1940, RG 25, vol. 2731, file 267-J-40C, vol. 1, LAC.

95 SSEA to Canadian Minister, No. 68, 9 May 1940, RG 25, vol. 2731, file 267-J-40C, vol. 1, LAC.

96 External Affairs to Canadian Minister, No. 67, 9 May 1940, RG 25, vol. 2731, file 267-J-40C, 


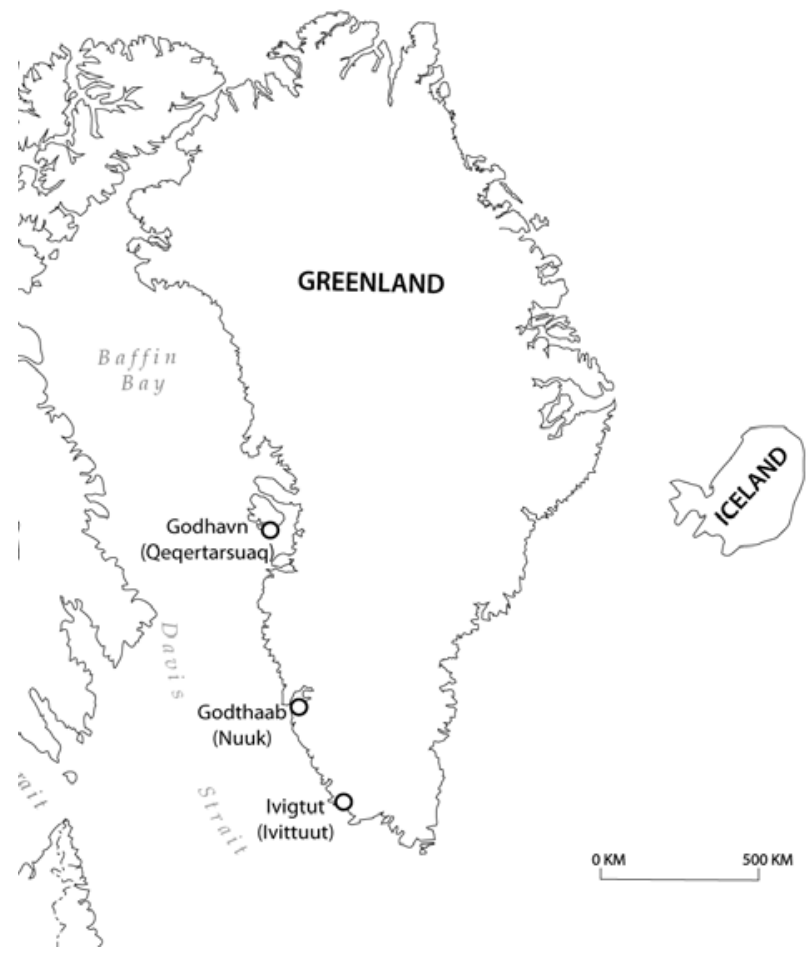

Map of Greenland during the Second World War. (Map produced and contributed by Dr. P. Whitney Lackenbauer)

Christie replied on 10 May, having already met with Berle and Moffat of the State Department and with the Danish Minister. Everyone said that they would welcome the appointment of a Canadian consul in Greenland, Kauffmann adding that it would be best if only the US and Canada took this step; and neither objected to the proposal for a locally manned gun. The State Department was ready to take part in discussions about the cryolite and welcomed the idea of a meeting. Most important from Ottawa's point of view, Berle agreed that the State Department must clarify its views regarding protection of the mine. ${ }^{97}$

On 15 May Cumming telephoned Reid and told him, among other things, that the State Department had "approved in principle the Canadian suggestion on the protection of Ivigtut." Evidently, he was referring to the proposal for a locally manned gun. On the "general question" of defence of the mines he said that this was "still a little open," but he expected that, by Friday, Berle would want Christie to come down for a discussion. ${ }^{98}$ On 16 May Cumming informed Mahoney that

vol. 1, LAC.

97 Canadian Minister to SSEA, No. 82, 10 May 1940, RG 25, vol. 2731, file 267-J-40C, vol. 1, LAC. See also Cordell Hull, The Memoirs of Cordell Hull, vol. 1 (New York: MacMillan Company, 1948), 757, where he says that the American Government accepted the idea of the gun, but thought that the Greenland authorities should obtain it from the US rather than from Canada.

98 Minute by Reid, 15 May 1940, RG 25, vol. 2731, file 267-J-40C, vol. 1, LAC. 
the Navy Department was preparing an outline of a minimum project for the defence of Ivigtut, which dealt mainly with the gun. By 20 May, the Department of State would be able to come to a decision on the matter, but was anxious that no communication about it should be sent to Greenland before the American consul had arrived, so that such messages could be sent in cypher. ${ }^{99}$

On 20 May, Dr. Keenleyside, who had gone to Washington, met with Berle and other State Department officials who told him that Comanche had arrived at Ivigtut that morning with Penfield aboard. Penfield would report as quickly as possible by wireless, and on that basis the US government would decide how much defensive armament was required at Ivigtut (which it would send on Campbell). The Navy's plan called for the dispatch of about sixty men to handle a shore battery, but this would probably be reduced. The Americans hoped that Greenlanders, or Danish resident in the United States, could be found to man the gun or guns that the US provided. When asked what action the US would take if it learned of an impending attack on Ivigtut, Berle "would only go so far as to say" that Washington would like to receive such information at the first possible moment, but that "suitable measures" would be taken. ${ }^{100}$

The Canadian government kept the British informed of these negotiations with Washington while they were in progress. In answer to Eden's letter of 2 May, a cable was sent to High Commissioner Massey on 10 May, instructing him to tell the British authorities that although the Canadian government recognized the logical weakness of Hull's analogy, it nevertheless accepted the American view that this weakness would not deter the Japanese from using Greenland as a precedent for action elsewhere. The Canadian government thought maintaining a direct and friendly American interest in both the Western Pacific and Greenland was "of the greatest importance," and that to "take action first and not inform the US until afterwards would be most inadvisable." Given that Washington had yet to propose a satisfactory alternative plan for protection of the cryolite, Massey was told of the interim measures being taken by Canada, including the dispatch of Nascopie, the plan to send a consul, and the proposal to the US about the gun. In conclusion, the cable suggested that Julius Thomsen should be held at Kirkwall until the situation had become clarified. ${ }^{101}$

99 M.M. Mahoney (for the Minister) to SSEA, No. 947, 16 May 1940, RG 25, vol. 2731, file 267-J-40C, vol. 2, LAC.

100 Memo by Keenleyside, 20 May 1940, RG 25, vol. 2731, file 267-J-40C, vol. 2, LAC. King's diary entry for May 26 includes the following: "The President agreed, however, to have his 'ice patrol' extend to Greenland; prepared to watch our coast and if a raid made on Greenland, to blow the raider to pieces...."

101 SSEA to High Commissioner, No. 516, 10 May 1940, RG 25, vol. 2731, file 267-J-40C, vol. 1, LAC. Another cable, sent to Massey on 12 May, observed that the American position as outlined marked "a definite advance," and asked for an indication of British views. This message was passed on to the Under Secretary of State for Dominion Affairs in closely paraphrased terms by Lester Pearson of the High Commission on 13 May. SSEA to High Commissioner, No. 525, 12 May 1940, and Pearson to Under Secretary of State for Dominion Affairs, 13 May 1940, RG 25, vol. 2731, file 267-J-40C, vol. 1, LAC. 
Massey sent an answering cable on 15 May, explaining that the British authorities agreed that it was essential to maintain American interest and that the US position marked an advance. The British welcomed the Canadian government's proposed action and noted that "while acting in concert with the United States Government they [the Canadian government] are willing to undertake responsibility for security of Greenland." Nevertheless, they wished to know what further action was contemplated and doubted whether the proposed arrangements were adequate. They suggested specifically that officers with artillery training and mining experience, and also RCMP members, be sent promptly to Ivigtut on Nascopie, which should remain there until the American cutter had arrived. Julius Thomsen was held at Kirkwall as Canada had requested, but it was essential to send it to Greenland without undue delay because it had supplies for the population and personnel and equipment for production of the cryolite. When it sailed a guard force would be placed on board to ensure that it would not be used in the interests of the enemy. ${ }^{102}$

Ottawa responded to Massey on 18 May, suggesting that Julius Thomsen be released in time to reach Ivigtut between 3 and 6 June, which would be shortly after the expected arrival of Nascopie. Massey was asked in blunt terms to make it clear to the Government of the United Kingdom that while "we have agreed to take certain steps and to endeavour to obtain the active participation of the United States in providing safeguards for Ivigtut, we have not at any time agreed 'to undertake responsibility for the security of Greenland." ${ }^{103}$ On 22 May Massey sent a cable to Ottawa saying that he had done this. ${ }^{104}$ In a telephone conversation with Escott Reid on 30 May, Keenleyside provided his own summary of the American attitude. "The United States has now reached the point where they are taking the responsibility for the defence of Greenland," Reid recorded. "In addition Canada has received assurances that the United States is prepared to go a great deal further. He said that he could not tell me the nature of these assurances over the telephone." When Reid reported this conversation to Lord Lothian the same day, however, the British ambassador "was not convinced that the measures which had been taken would be effective against a sudden raid by Germany. He said that the truth of the matter was that the British navy was still defending Ivigtut." Merchant Mahoney of the Canadian Legation agreed, saying that "U.S. efforts so far would scarcely prove effective against a first-class German raider." 105

On 9 May Skelton asked Roy Gibson of the Department of Mines and

102 High Commissioner to SSEA, No. 606, 15 May 1940, RG 25, vol. 2731, file 267-J-40C, vol. 1, LAC. See also S.L. Holmes (Dominions Office) to Secretary High Commission, 15 May 1940, RG 25, vol. 2731, file 267-J-40C, vol. 2, LAC.

103 SSEA to High Commissioner, No. 562, 18 May 1940, RG 25, vol. 2731, file 267-J-40C, vol. 2, LAC.

104 High Commissioner to SSEA, No. 661, 22 May 1940, RG 25, vol. 2731, file 267-J-40C, vol. 2, LAC.

105 Minute by Reid, and marginal comment thereon by Mahoney, 30 May 1940, RG 25, vol. 2731, file 267-J-40C, vol. 2, LAC. 
Resources to have Ralph Parsons of the Hudson's Bay Company make immediate arrangements, without any publicity, for the dispatch of Nascopie. ${ }^{106}$ These preparations went ahead steadily during the next two weeks, ${ }^{107}$ and on 17 May the Cabinet War Committee approved proposals "for the mounting of a gun, the provision of an RCMP detail, and others, to proceed on the voyage." 108 Officials later decided not to wait for the mounting of the gun, however, because it would interfere with more pressing work being done at Halifax where Nascopie was being outfitted, it would take valuable time, and in any case it was assumed that by the time Nascopie got to Greenland more heavily armed American vessels would be there already. ${ }^{109}$ Because of unavoidable circumstances it was necessary to finish coaling at Louisburg instead of Sydney, and by 24 May the ship was ready to sail. ${ }^{110}$ Ultimately, federal officials decided that she should take three Vickers machine guns, sixty rifles, and adequate ammunitions, and that the RCMP detail should comprise two constables in uniform and four special constables not in uniform but able to operate the machine guns. In addition, she should take an experienced artillery officer in civilian dress, three engineers representing the Aluminum Company of Canada (although only two were sent), and various foodstuffs and other supplies. As had been the case for the northern voyages of Nascopie since 1932, the commander of the government party was David Livingstone McKeand and the master of the ship was Captain Thomas Farrar Smellie. ${ }^{111}$

The arrangement to send the artillery officer was made at an interdepartmental meeting in the office of the Deputy Minister of Mines, Dr. Charles Camsell, on 18 May. Major G.L.W. Macdonald, Royal Canadian Artillery, was selected as the officer to carry out the assignment. ${ }^{112}$ "Most Secret and Personal" instructions were written for him the same day, which he was ordered to study and then burn. The main details of his responsibilities were set forth as follows:

The specific reason for your visit to Greenland will be to carry out a reconnaissance of the environs of Ivigtut and select locations for the installation of two 4.7" C.D. Equipments and two Defence Electric Lights. In the foregoing connection you will bear in mind that the primary

\footnotetext{
106 Skelton to Gibson, 9 May 1940, RG 25, vol. 2731, file 267-J-40C, vol. 1, LAC.

107 Skelton to Gibson, 9 May 1940, RG 25, vol. 2731, file 267-J-40C, vol. 1, LAC.

108 Minutes of the Cabinet War Committee, Meeting No. 4, May 17, 1940, 7, LAC. But see King Diaries, no. 147, 497, 17 May 1940, LAC, where the diary entry is at variance with the minutes respecting the gun: "We cleared up further particulars about the 'Nascopie,' Crerar at last having found out what his Department was doing. Arranged not to trouble about placing the gun on board, but to have a detachment [sic] of Mounted Police along with some military engineer who could be an observer."

109 C.G. Power to Skelton, 16 May 1940; Skelton to T.A. Crerar, 18 May 1940, RG 25, vol. 2731, file 267-J-40C, vol. 2, LAC.

110 McKeand to Gibson, 23 May 1940, RG 25, vol. 2731, file 267-J-40C, vol. 2, LAC.

111 Gibson to McKeand, 18 May 1940; Skelton to Crerar, 18 May 1940; Gibson to Smellie, 20 May 1940; Powell to McKeand, 20 May 1940, RG 25, vol. 2731, file 267-J-40C, vol. 2, LAC.

112 Gibson to McKeand, 18 May 1940; HQS 8559, Gibson to DND, 18 May 1940; Maj. Gen. Anderson, CGS, to Minister, 18 May 1940, RG 25, vol. 2731, file 267-J-40C, vol. 2, LAC.
} 
object of the defences, insofar as the capabilities of the armament and lights will permit, is the immediate protection of the Cryolite mine at Ivigtut against direct enemy action.... In addition ... you will note and record as much information as possible which you consider might be of use should it be decided later to despatch an expedition ... [and] you will be scrupulously careful that your actions do not disclose the purpose of your presence in Greenland. This restriction may prevent you from actually visiting possible locations for guns and lights. ${ }^{113}$

Obviously, the idea of a later military expedition was still afoot and, at least so far as Macdonald's role was concerned, all this expedition's cards were not on the table.

Planned telegrams were sent on 15 May to Administrators Eske Brun and Axel Svane of North and South Greenland respectively, informing them of Canada's concern over the fall of Denmark and offering Canadian help for Greenland. The telegrams gave information about Nascopie and the goods she carried. They also expressed Canada's worry about the safety of the cryolite, as well as hope that Greenland and American authorities were open to arranging consultations about production and distribution of the ore - with Nascopie ideally bringing back a cargo on her return. ${ }^{114}$ The administrators replied in polite but rather noncommittal terms in a joint communiqué on 17 May, suggesting that the American-Danish Committee in New York be advised about the supplies and provide more information about the export of cryolite later. ${ }^{115}$

In the meantime, officials in Ottawa considered the appointment of a Canadian consul for Greenland. Initially King and Crerar had in mind "a competent Canadian of Danish or Icelandic descent," 116 and senior Cabinet ministers J.G. Gardiner and C.D. Howe recommended suitable candidates. ${ }^{117}$ Kenneth P. Kirkwood, a foreign service officer who had been Canada's representative at The Hague, had become available following the invasion of Holland, however, and appointing a professional diplomat would match the status of the American in Greenland. Accordingly, King decided in favour of Kirkwood, with Porsild appointed vice consul to assist him. ${ }^{118}$ The two appointments simplified the problem of transportation because Kirkwood was able to go to Greenland directly from Great Britain on Julius Thomsen, while Porsild had already been assigned to the Nascopie party. At the request of the

113 DMO \& I to Maj. Macdonald, 18 May 1940, RG 25, file 8559, microfilm reel no. C-8365, LAC.

114 Draft telegrams to North and South Greenland, 15 May 1940, RG 25, vol. 2731, file 267-J-40C, vol. 1, LAC.

115 Svane and Brun to SSEA, 17 May 1940, RG 25, vol. 2731, file 267-J-40C, vol. 2, LAC.

116 Skelton to Beaudry, 14 May 1940, RG 25, vol. 2731, file 267-J-40C, vol. 1, LAC.

117 Memo by Skelton for PM, 15 May 1940; Memo by Skelton (for file?), 15 May 1940, RG 25, vol. 2731, file 267-J-40C, vol. 1, LAC.

118 Memo by Skelton (for file?), 15 May 1940; SSEA to High Commissioner in U.K., for Kirkwood, 20 May 1940; Skelton to Porsild, 20 May 1940; Skelton to Crerar, 20 May 1940; Skelton to Gardiner, 20 May 1940; Memo by Skelton for PM, 21 May 1940, RG 25, vol. 2731, file 267-J-40C, vol. 1, LAC. 
Canadian government, the royal commission of appointment made no mention of Denmark, but simply appointed Kirkwood consul in Greenland. ${ }^{119}$ Identical letters were written to Svane and Brun on 20 May, informing them of the two appointments. ${ }^{120}$ On the same day Kauffmann sent word to the administrators about the Canadian consul, and on 21 May received a telegram from them saying that he would be welcome - but that it would be necessary to send lumber for Kirkwood's accommodations because the Greenlandic authorities had none at their disposal. ${ }^{121}$ The Canadian government took the additional step of asking G.B. Holler, the Danish Consul General in Montreal, to communicate with the administrators in order to ascertain officially whether the provisional establishment of a consulate was satisfactory and if provisional recognition might be given. ${ }^{122}$ After some misunderstanding over its form and content ${ }^{123}$ the communiqué was sent on 1 June, ${ }^{124}$ and on 5 June Holler received an answering cable signifying approval, but reiterating that housing materials would have to be sent from Canada. ${ }^{125}$

Meanwhile, the Canadian and American governments, the Canadian and American companies handling the cryolite, and the American-Danish Greenland Commission met in New York on 21 May to discuss the protection, production, transportation, and allotment of the Greenland cryolite. ${ }^{126}$ Participants agreed that the two governors in Greenland had the authority to assume absolute control in the event of an emergency, and thus their assumption of such control after the German occupation of Denmark had been legal. Keenleyside suggested that either Canadian members should be added to the existing American-Danish Greenland Commission or a parallel organization set up in Canada and Sonne agreed. Participants debated the legal status of the contracts made before the German occupation, prior to reaching a general agreement that Greenland authorities were free to dispose of that portion of the cryolite which had previously gone to the refinery at Copenhagen. On the all-important subject of cryolite, Keenleyside explained that the Canadian

119 SSEA to Secretary of State for Dominion Affairs, No. 83, 21 May 1940 and Secretary of State for Dominion Affairs to SSEA, No. 65, 29 May 1940, RG 25, vol. 2731, file 267-J-40C, vol. 2, LAC.

120 Skelton to Svane and Brun, 20 May 1940, RG 25, vol. 2731, file 267-J-40C, vol. 2, LAC.

121 Minute by Reid, 22 May 1940 and Kauffmann to Reid, 22 May 1940, RG 25, vol. 2731, file 267-J-40C, vol. 2, LAC.

122 Skelton to Holler, 21 May 1940, RG 25, vol. 2731, file 267-J-40C, vol. 2, LAC.

123 Memo by L. Beaudry, 25 May 1940; Holler to Skelton, 27 May 1940; Beaudry to Holler, 30 May 1940; Holler to Skelton, 31 May 1940; Holler to Beaudry, 31 May 1940, RG 25, vol. 2731, file 267-J-40C, vol. 2, LAC.

124 Memo by Beaudry, 1 June 1940; Holler to Skelton, 5 June 1940, RG 25, vol. 2731, file 267-J-40C, vol. 2, LAC.

125 Holler to Skelton, 5 June 1940; Brun and Svane to Holler, 4 June 1940, RG 25, vol. 2731, file 267-J-40C, vol. 2, LAC.

126 Secretary of State for External Affairs to Minister in Washington, No. 68, 9 May 1940; Canadian Legation to External Affairs, No. 82, 10 May 1940; No. 83, 13 May 1940, RG 25, vol. 2731, file 267-J-40C, vol. 1, LAC. See also SSEA to Canadian Minister, No. 73, 15 May 1940, RG 25, vol. 2731, file 267-J-40C, vol. 1, LAC, giving more precise instructions about proposals for the meeting to be presented to both the State Department and Danish Minister Kauffmann. 
government felt that it should have a voice in determining the distribution of the twothirds portion of the ore not already allotted to Penn Salt and now available (some of which should go to the Aluminum Co. of Canada). Canada's primary concern was to make sure that the Allies received sufficient cryolite for war purposes, and secondarily to strengthen its wartime economy. Officials also wanted to prevent any supply from going to Germany (something which everyone agreed must not happen) and wanted security from possible policy changes by Penn Salt or the US government. In response, Beale proposed that Penn Salt should determine who received the cryolite - with Sonne approving of it because Penn Salt was representative of a neutral country. Keenleyside, unwilling to accept a proposal that could deprive Canada of increased production, said that there was nothing to justify subordinating the Aluminum Co. to Penn Salt. Cumming subsequently told Sonne that the US government would undoubtedly want to determine its interests in the matter before reaching a final agreement, and arranged for Sonne, Powell, and Beale to meet the following morning to work out a settlement. ${ }^{127}$

On 22 May, Powell and Beale accepted a compromise settlement proposed by Sonne that would have to be approved by both Canadian and American governments ${ }^{128}$ and by the Greenland authorities. ${ }^{129}$ Discussions continued intermittently for more than two months before all formalities connected with the agreement were completed. Succinctly stated, Greenland would sell the cryolite, directly and exclusively, to the Penn Salt Co. and the Aluminum Co. of Canada, always at the same prices and terms. The "North American market" would be supplied according to need: the Canadian company would supply cryolite for the metallurgical industries of Great Britain, France, and other Allies, and there were certain provisions for other parts of the world, exclusive of Germany. The arrangement was to last for the duration of the war and a short, specified time thereafter. This satisfied Canada's interests, assuring the country an adequate supply (or at least an adequate proportion of the output) of the Greenland cryolite without having to depend upon the Penn Salt Co. as an intermediary. ${ }^{130}$

On 3 June, Chargé d'Affaires Merchant Mahoney called at the office of

127 Memos by Cumming, 21 May 1940, Reid, 22 May 1940, and revision of Reid's memo by Keenleyside (n.d.); also Skelton to Chargé d'Affaires in Washington, No. 381, 7 June 1940, RG 25, vol. 2731, file 267-J-40C, vol. 2, LAC.

128 Minute by Reid, 23 May 1940, RG 25, vol. 2731, file 267-J-40C, vol. 2, LAC.

129 SSEA to High Commissioner in London, No. 728, 13 June 1940, RG 25, vol. 2731, file 267-J-40C, vol. 2, LAC.

130 Draft of contract between Government of Greenland, Penn Salt Co., and Aluminum Co. of Canada, 4 June 1940, RG 25, vol. 2731, file 267-J-40C, vol. 2, LAC. See also Sonne to Keenleyside, 17 June 1940; Minute by Reid, 18 June 1940; later drafts of agreement between Ivigtut Kryolith Mines and Aluminum Co. of Canada, 23 and 30 July 1940; notes by Keenleyside on meeting of 17 July in New York, 19 July 1940; Minutes by Keenleyside of meeting 29 July in Ottawa of representatives of Greenland and Canada, 29 July 1940, RG 25, vol. 2731, file 267-J-40C, vol. 3, LAC; Draft of agreement between Ivigtut Kryolith Mines and Penn Salt Co., 3 August 1940, RG 25, vol. 2731, file 267-J-40C, vol. 3, LAC. 
Assistant Secretary of State Berle, at the latter's request, for what turned out to be an embarrassing and awkward interview. In effect, he had the riot act read to him over Canada's behaviour with respect to Greenland. Berle said that up to the present the American and Canadian governments had been working in harmony over Greenland, but now he had received some information which disturbed him. Nascopie had arrived at Ivigtut on 1 June, to find that the American cutter Comanche had been there since 20 May. Julius Thomsen arrived from Kirkwall on 4 June, while the second American cutter, Campbell, had gone on to Godthaab before Nascopie arrived. After the Canadian and British vessels arrived, the State Department learned that Julius Thomsen had on board not only the Canadian consul (Kirkwood), but also three British naval officers. Furthermore, he had received information that Nascopie had on board not only Vice Consul Porsild, an artillery officer in mufti, and two mining engineers from the Aluminum Co. of Canada (about whom the United States had been told), but also some RCMP officers and soldiers. He found this news disturbing, since the presence of military personnel might be interpreted as meaning that the Canadian government intended to take control of Greenland, while the inclusion of the mining engineers made him fear that the Aluminum Co. of Canada was trying to get control of the cryolite mines. He wanted to know why these people had been sent and whether they intended to stay in Greenland. In reporting the interview, Mahoney said that Berle "was very blunt and stated that the President had said he would be 'very angry' if Canada attempted to occupy Greenland." Berle added that "this was not the time for this type of 1890 imperialism and that the days of Cecil Rhodes had passed." ${ }^{31}$ The next morning, Cumming phoned the Canadian Legation to say that Kauffmann had just received a telegram from the Greenland authorities, expressing anxiety about the additional people on Nascopie and the possibility of an occupation, and asking that the US send landing parties. ${ }^{132}$

This turn of events caused consternation in Ottawa. In a memo to King, Skelton said that Berle's tone was "wholly unwarranted." 133 On 4 June, King's advisor told Mahoney to give Berle the following information without delay:

(1) Julius Thomsen. We have been informed that the United Kingdom placed a temporary guard on this vessel to prevent sabotage and to see that it did in fact go to Greenland as ordered. This seems to us to be a reasonable minimum precaution.

131 L. Mahoney to SSEA, Telegram No. 106, 3 June 1940; Mahoney to SSEA, Dispatch No. 1089, 3 June 1940, RG 25, vol. 2731, file 267-J-40C, vol. 2, LAC. Berle's diary entry for June 3 contains the following: "This is all right if these people are going to inspect and go back; but if it is a landing party, we don't like it. ... I asked for an immediate answer.... I hope the Canadians and English accept my not too diplomatic invitation to have a drink on the Governor of Greenland and go home." Quoted in Finn Løkkegaard, Det danske Gesandtskab i Washington (København: Gyldendal, 1968), 542, fn. 73. 132 Minute by Reid, 4 June 1940, RG 25, vol. 2731, file 267-J-40C, vol. 2, LAC. See Hull, Memoirs, vol. 1, 757, for the statement that on 3 June the Greenland governors asked Penfield for a US landing force as soon as possible. Did Berle know of this request when he spoke to Mahoney the same day? 133 Memo by Skelton for PM, 4 June 1940, RG 25, vol. 2731, file 267-J-40C, vol. 2, LAC. 
(2) We did not state that there would be artillery "officers" on the Nascopie. We informed Mr. Berle that one such "officer" in plain clothes would make the round trip. This is what is being done.

(3) There is no Royal Canadian Mounted Police Officer on the Nascopie. Two constables were sent and four civilians were deputized to assist in handling the two machine guns which with one spare and a few rifles constituted the total defensive equipment carried by the Nascopie. (This of course does not in any way compare with the armament carried by the US Coast Guard cutters). The Nascopie always carries members of the RCMP on its northern trips.

(4) There are no soldiers on the Nascopie other than the one officer referred to above.

(5) The whole complement of the Nascopie will return on that ship.

(6) The only way in which the Aluminum Company of Canada enters the picture is in connection with the negotiations regarding the division of the cryolite which are now proceeding with Penn Salt, the outcome of which, as Mr. Berle knows, is subject to review by both Governments.

(7) Even if the erroneous reports received by the State Department were true it is difficult to see how they could be interpreted as a Canadian attempt "to occupy Greenland". We have already informed the United States that we have no intention of occupying Greenland.

You may then add that from the first the Canadian government had kept the Government of the United States fully informed of all its plans relating to Greenland. In return we feel justified in asking that our statements be accepted by the officials of the State Department. ${ }^{134}$

This telegram was followed on 5 June by a letter, which, after amplifying to some extent certain of the points made in the telegram, concluded as follows: "It is not, I believe, necessary to comment further on Mr. Berle's suspicion that the Canadian government may be attempting to secure control of Greenland or upon the rather extraordinary analogies drawn in the 8th paragraph of your dispatch" - which contained the remarks about " 1890 imperialism" and "the days of Cecil Rhodes." 135

The cold reception accorded Nascopie at Ivigtut showed the suspicion with which the local inhabitants and officials regarded the expedition and Canadian motives generally. Relations did not improve over the next three weeks owing to an unfortunate series of misunderstandings and faux pas, some avoidable and some unavoidable. The local controller, Albrecht Fischer, came aboard as soon as

\footnotetext{
134 SSEA to Chargé d'Affaires in Washington, Telegram No. 94, 4 June 1940, RG 25, vol. 2731, file 267-J-40C, vol. 2, LAC.

135 SSEA to Chargé d'Affaires in Washington, unnumbered letter, June 5, 1940, RG 25, vol. 2731, file 267-J-40C, vol. 2, LAC. It is worthy of mention that Prime Minister King, who had written so much in his diary a few weeks earlier about Greenland and the need for cohesion in American and Canadian action there, wrote nothing whatever on the subject at this rather strained and unsatisfactory stage.
} 
Nascopie arrived on 1 June, and thus immediately became aware of the artillery officer, the RCMP, the small arms and ammunition, and the mining engineers, all of which seemed to confirm suspicions about Canada's motives. All the assurances the Canadians could give were not sufficient entirely to remove local distrust.

The arrival of Julius Thomsen on 4 June, with the British naval guard in actual control of the vessel, did not improve matters. Kirkwood, who was also on board, did everything in his power to set matters right, but to no avail. Unfortunately, initial and rather hesitant mutual invitations between Fischer and Major McKeand had been declined on both sides, and both Danes and Canadians concurred that all activity and all decisions should await the arrival of Kirkwood, and then of Governor Svane, who after some delay arrived from Godthaab on board Campbell on 13 June. ${ }^{136}$ In addition, the Nascopie party received clear direction that only civilians would be welcome ashore. McKeand took umbrage because for years RCMP personnel on the Eastern Arctic Patrol had participated in visits to Greenland ports. For these and other reasons Nascopie's company stayed aboard, or were kept aboard, for about three weeks as they waited at Ivigtut. Only two or three men, including the ship's doctor and Porsild, went ashore. ${ }^{137}$ The naval guard of officers and men aboard Julius Thomsen were also denied permission to land. ${ }^{138}$

The Greenland authorities, who had "officially" announced their takeover of the mine on 3 June, ${ }^{139}$ also were anxious to take over Julius Thomsen, which would be extremely useful in Greenland's trade. ${ }^{140}$ Initial requests for the transfer of the

136 Kirkwood to SSEA, No. 3, 6 June 1940; No. 8, 14 June 1940, RG 25, vol. 2731, file 267-J-40C, vol. 2, LAC; McKeand to Gibson, 2 July 1940; Minutes of meetings aboard Nascopie, 1 and 12 June 1940, by F.R.E. Sparks, Secretary, RG 25, vol. 2731, file 267-J-40C, vol. 3, LAC. See also Kirkwood to SSEA, Dispatch No. 6, 14 July 1940, RG 25, vol. 2731, file 267-J-40C, vol. 3, LAC. The assurances given Fischer that Macdonald "had no duties or instructions of military character concerning Greenland" were obviously incorrect, but perhaps no one aboard Nascopie knew this except Macdonald himself. Kirkwood, who obviously could not have been fully informed about these matters before his arrival, observed that "there evidently had been widespread rumours that the Canadian Government proposed to send Canadian troops to Greenland. I had no information whatever on this matter, but the rumour may have reached the ears of the Greenland authorities...." At the same time there was a strong tendency in both Greenland and the US to identify the Aluminum Co. of Canada as the real instigator of Canadian action, and on the evidence there was certainly a considerable measure of truth in this. See, for instance, Løkkegaard, Det danske Gesandtskab $i$ Washington, 617: "The Aluminium Company of Canada (Alcan) was no doubt behind the expedition.... Undoubtedly the company wished to take over the mining...."; also Langer and Gleason, Challenge to Isolation, 685: "Canadian aluminum interests were at the same time maneuvering to get control of the entire output of the mine...." However, and contrary to a widely-held supposition among nonCanadians at the time, it was not true that the Company was the actual organizer and director of the expedition behind the scenes.

137 McKeand to Gibson, 2 July 1940, RG 25, vol. 2731, file 267-J-40C, vol. 3, LAC.

138 Kirkwood to SSEA, No. 7, 12 June 1940, RG 25, vol. 2731, file 267-J-40C, vol. 2, LAC.

139 Kauffmann to Christie, 11 June 1940, informing him of the takeover, RG 25, vol. 2731, file 267-J-40C, vol. 2, LAC.

140 Kirkwood to SSEA, No. 2, 6 June 1940; No. 6, 12 June 1940, RG 25, vol. 2731, file 267-J-40C, vol. 2, LAC; and No. 12, 19 June 1940, RG 25, vol. 2731, file 267-J-40C, vol. 3, LAC. 
vessel aroused a favourable response in Ottawa and London. ${ }^{141}$ Governor Svane, however, evidently smarting under the humiliation of seeing a British occupying party in control, unwisely decided to adopt stronger and speedier measures. On 16 June, he informed Kirkwood that he had taken over the vessel on behalf of the Greenland government, his immediate purpose being to send it to the United States bearing a load of cryolite and also several Greenland representatives who were to carry on important discussions with American officials. ${ }^{142}$ Three days later, Commander Hood and his small naval guard were peremptorily ordered by an unsigned radiogram to transfer to Nascopie. McKeand refused to accept them on grounds that such an unsigned order could not be regarded as official, and he insisted upon having instructions from Ottawa. A midnight conference with Governor Svane resulted in an agreement that the order would be rescinded and that McKeand would request the desired instructions. ${ }^{143}$ In fact, orders were already on their way from London via Ottawa that Hood was to stay aboard Julius Thomsen and keep it in Greenland waters pending clarification of its status. ${ }^{144}$ Both Great Britain and Canada informed Svane that his unilateral takeover would not be accepted, and both the American-Danish Greenland Commission and the Danish Minister in the US also disapproved of his action. ${ }^{145}$ When he received word that the ship would be permitted to make a voyage to the US with the naval guard aboard, he replied that this would be acceptable for the cryolite but not for the Greenland officials (who eventually went on Campbell). ${ }^{146}$

All this confusion, and the maze of conflicting orders and arrangements, made it difficult for Nascopie to unload her cargo and replace it with cryolite. A rapidly changing series of plans first called for the vessel to deliver its cargo to Godthaab and Godhavn, then determined that Julius Thomsen would take on the

\footnotetext{
141 SSEA to Kirkwood, No. 5, 19 June 1940, RG 25, vol. 2731, file 267-J-40C, vol. 3, LAC.

142 Kirkwood to SSEA, No. 9, 17 June 1940 and Kirkwood to Keenleyside, 26 June 1940, RG 25, vol. 2731, file 267-J-40C, vol. 3, LAC.

143 McKeand to Gibson, 2 July 1940, RG 25, vol. 2731, file 267-J-40C, vol. 3, LAC. A further note written by McKeand on July 2, making at least three bearing this date, claims that his refusal to accept the British naval guard on Nascopie was the decisive factor in getting permission for the vessel to unload. See Minutes of meeting aboard Nascopie, 20 June 1940, by Secretary Sparks, RG 25, vol. 2731, file 267-J-40C, vol. 3, LAC. In a personal letter of 3 August 1940, to Keenleyside, Kirkwood advised him to accept McKeand's impressions "with greatest reserve" or "to disregard them". Referring to the Aluminum Co. of Canada, he said that it had "sent Hendra up on a wild-goose chase," and that his "apparent instructions...to negotiate for the purchase of the total cryolite output or even the outright purchase of the Danish Government-owned Mine by the Canadian corporation, were ill-judged and misinformed, and created an atmosphere of suspicion here that was difficult to dispel.” RG 25, vol. 2731, file 267-J-40C, vol. 4, LAC.

144 SSEA to Kirkwood, No. 2, 17 June 1940 and McKeand to Gibson, 2 July 1940, RG 25, vol. 2731, file 267-J-40C, vol. 3, LAC.

${ }_{145}$ SSEA to Kirkwood, No. 5, 19 June 1940; SSEA to High Commissioner in London, No. 774, 19 June 1940; Sonne to Keenleyside, 17 June 1940; Minute by Reid, 15 June 1940, RG 25, vol. 2731, file 267-J-40C, vol. 3, LAC.

146 Kirkwood to SSEA, Dispatch No. 2, 24 June 1940, RG 25, vol. 2731, file 267-J-40C, vol. 3, LAC.
} 
United States

Coast Guard Cutter

Campbell.

(Wikimedia Commons)

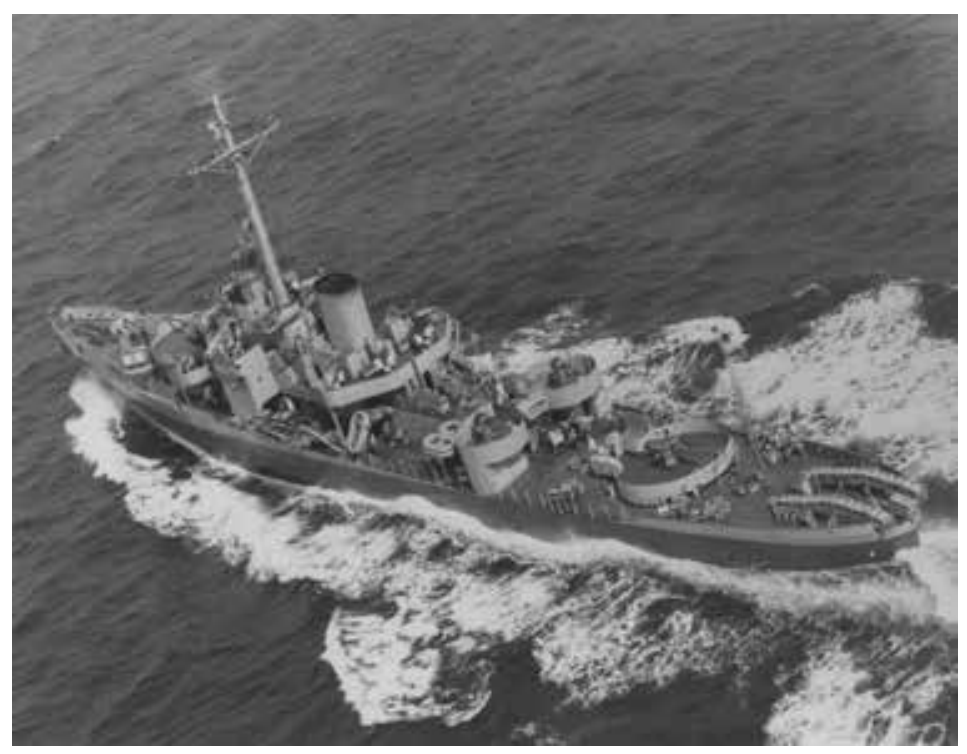

cargo, before a final decision was made to unload the cargo on the quay at Ivigtut so that Nascopie could take on a load of cryolite without further delay. This last arrangement was made on 21 June and work began promptly. ${ }^{147}$ By the evening of the 27 June, Nascopie had her load of cryolite and was ready to sail. ${ }^{148}$ After bad weather caused a delay, the ship finally departed on the 29th, while Julius Thomsen and Campbell set sail for the United States the same day, the former with instructions to leave the British naval personnel at a Canadian port on the way. ${ }^{149}$

In the meantime, negotiations proceeded for the transfer of Julius Thomsen from British to Greenland registry and, after a certain amount of haggling, concluded satisfactorily. The Canadian government strongly urged the British to agree to the transfer without delay, even if it were necessary to leave details to be worked out later. ${ }^{150}$ On 26 June, Massey sent word of the British government's acceptance, "subject to satisfactory undertakings" from the Greenland government. ${ }^{151}$ These

\footnotetext{
147 See also McKeand to Gibson, 2 July 1940, RG 25, vol. 2731, file 267-J-40C, vol. 3, LAC. In his dispatch of 24 June Kirkwood reported that in spite of all the confusion and suspicion there was "no want of satisfaction and appreciation" with respect to the supplies.

148 McKeand to Gibson, 2nd letter of 2 July 1940, RG 25, vol. 2731, file 267-J-40C, vol. 3, LAC.

149 SSEA to Kirkwood, No. 8, 21 June 1940; Kirkwood to SSEA, No. 18, 29 June 1940, RG 25, vol. 2731, file 267-J-40C, vol. 3, LAC.

150 SSEA to Massey, No. 774, 19 June 1940; No. 783, 20 June 1940, RG 25, vol. 2731, file 267-J-40C, vol. 3, LAC.

${ }^{151}$ Massey to SSEA, No. 970, 26 June 1940, RG 25, vol. 2731, file 267-J-40C, vol. 3, LAC. On the legal aspects of the seizure and transfer of the Julius Thomsen, see Keenleyside to Kirkwood, 24 August 1940, RG 25, vol. 2731, file 267-J-40C, vol. 4, LAC: "it might be pointed out to the Greenland authorities that this ship was taken over by the United Kingdom Government in the same way that all other Danish ships were seized following the occupation of Denmark by Germany. There is no obligation on that Government to give the ship to the Greenland authorities, as it was a vessel of Danish registry and quite properly subject to the Prize proceedings which had been taken against it. I
} 
"undertakings" were chiefly that the Greenland government would assume the moral obligation of the British government to return the vessel to its Danish owners after the war and pay compensation for its use; use the vessel exclusively "in Allied interests"; and conclude the requisite formal agreement. ${ }^{152}$ The Greenland authorities were willing to accept these conditions, except that they wanted to have the phrase "in Allied interests" eliminated from the draft agreement so that there would be no infringement of their neutral status. ${ }^{153}$ The British government, however, only accepted a modification which made the passage read "in Allied interests unless otherwise agreed." 154 The draft agreement was signed in Ottawa on 30 July by Governor Eske Brun and British High Commissioner Sir Gerald Campbell, during the visit of the Greenland delegation to North America. ${ }^{155}$

In spite of the initial American determination to maintain a "Hands Off" policy respecting Greenland, and the accompanying hope that actual commitment of American military resources to defence of the island could be avoided, the United States' involvement increased over time. Both Comanche and Campbell carried arms during their first voyage to Greenland. McKeand, Major Macdonald, and Kirkwood all reported the unloading of a 3-inch gun, some smaller weapons, and supplies of ammunition from Campbell after her arrival at Ivigtut on 13 June. ${ }^{156}$ Kirkwood added that he thought these measures were being taken not only for defence purposes but also to serve as a deterrent to disaffection and sabotage among the mine workers themselves and to help bolster the morale of the local population. Assurances were quickly given by the Department of External Affairs that the Canadian government knew of and fully approved the American action. Skelton, for example, wrote to Col. J. Muchie of the Department of National Defence with respect to Macdonald's report: "We were informed by the United States Government before this action was taken and, in fact, the whole procedure was the result of a suggestion made by Canada. Under the circumstances, far from

think it would not be unfair to say to Governor Svane that if it had not been for Canadian intervention the vessel would not have been released to Greenland."

${ }_{152}$ Massey to SSEA, No. 927, 21 June 1940 and Sir Gerald Campbell to SSEA, No. 24, 10 July 1940, RG 25, vol. 2731, file 267-J-40C, vol. 3, LAC.

153 Kirkwood to SSEA, No. 19, 29 June 1940 and Draft Agreement, 26 July 1940, RG 25, vol. 2731, file 267-J-40C, vol. 3, LAC. In the draft agreement, the phrase "and not against the Allied interest" is substituted.

154 C.A.E. Shuckburgh (British High Commission) to Keenleyside, 5 August 1940, RG 25, vol. 2731, file 267-J-40C, vol. 4, LAC.

${ }_{155}$ Draft agreement, 30 July 1940, RG 25, vol. 2731, file 267-J-40C, vol. 4, LAC. The modification which was the limit Britain would concede was made later. Shuckburgh to Keenleyside, 5 August 1940 and Keenleyside to Shuckburgh, 6 and 7 August 1940, RG 25, vol. 2731, file 267-J-40C, vol. 4, LAC. The reason for a measure of uncertainty here is that the copy of the document dated July 30 has the wording the British officials wanted, yet the later correspondence, cited here, deals with having this wording incorporated in the agreement.

156 McKeand to Gibson, 2 July 1940; Kirkwood to SSEA, No. 9, 16 July 1940; Colonel J.C. Murchie to Keenleyside, 20 July 1940, quoting extract from Macdonald's report, RG 25, vol. 2731, file 267-J-40C, vol. 3, LAC. 
having any objection to the landing of these armaments, we were very much in favour of that action." 157

On 16 July, the Canadian Legation in Washington informed Ottawa that Hugh Cumming had spoken of a State Department plan to release about ten to fifteen members of the US Coast Guard to serve the mine company at Ivigtut as "mine guards" responsible for the operation of the guns provided by the US. ${ }^{158}$ On 2 September, Kirkwood reported the arrival on Julius Thomsen of one officer and thirteen "ex-coast guard men" to carry out this function, commenting at the same time on the uneasiness and discontent among the mine workers. ${ }^{159}$ By 17 September, he reported that the arrangement was satisfactory to neither guards nor workers, because of increased crowding and growing tensions, and it was "open to question" whose tempers would "be frayed first." US Coast Guard cutters maintained a presence in Greenland waters throughout the summer and fall; and, evidently at Governor Svane's nervous insistence, at least one was always present at Ivigtut. ${ }^{160}$ In his communiqués to Ottawa, Kirkwood spoke with obvious envy and concern of the growing American presence and influence in Greenland:

The United States Government is certainly making a most impressive effort of godfathering this orphan island, and one wonders what is to [be] the ultimate result of it all. While Canada shares with Great Britain in the gigantic task of breaking the power of the Nazi domination of Europe and thus rescuing Denmark from its present thraldom and restoring Greenland to its proper parent, the USA. gets the job of, and the credit for, nursing the orphaned child. This job is being carried out with efficiency and generosity. ${ }^{161}$

Although Canada, in her circumscribed role, could not possibly match American performance in Greenland, relations between Canada and Greenland gradually improved. The abandonment of the projected military expedition and the realization by Greenlanders that such an expedition was not in the offing, along with the settlement of principal issues such as disposal of the cryolite and addition of Canadian representatives to the American-Danish Greenland Commission, removed the major possibilities for friction. Thanks to the patient efforts of

\footnotetext{
157 Skelton to Murchie, draft signed by Keenleyside, 24 July 1940, RG 25, vol. 2731, file 267-J-40C, vol. 3, LAC. Murchie's letter and the reply to it may be seen also in file H.Q.S. 8559, DHH. See also RG 25, vol. 2731, file 267-J-40C, vol. 4, LAC, for a letter in the same vein from Keenleyside to Kirkwood. King's diary entry for August 17 (792-93) includes the following: "In conversation with the President, he referred to having added a revenue cutter or two referring to Greenland. He said Lothian had spoken of Canada and England being concerned about Greenland. I told him my understanding was that everything in that connection had been satisfactorily arranged. That Canada and the US each had Consuls at Greenland, and were working together there. The President said if anything more were needed, let it be done without his having knowledge of it."

158 Canadian Minister to SSEA, 16 July 1940, RG 25, vol. 2731, file 267-J-40C, vol. 3, LAC.

159 Kirkwood to SSEA, No. 42, 2 September 1940, RG 25, vol. 2731, file 267-J-40C, vol. 4, LAC.

160 Kirkwood to SSEA, Dispatch No. 13, 17 September 1940, 1940, RG 25, vol. 2731, file 267-J-40C, vol. 4, LAC.

161 Kirkwood to Keenleyside, 8 August 1940, RG 25, vol. 2731, file 267-J-40C, vol. 4, LAC.
} 
Kirkwood in Greenland and senior officials in Ottawa, a more relaxed and friendly atmosphere was soon achieved. On 24 September, Kirkwood reported in a letter to Keenleyside that Oscar Corp, the manager of the mine at Ivigtut, had returned from the visit he and other Greenland officials had made to the United States and Canada "full of enthusiastic references to his Canadian visit ... much impressed with his hospitable reception.... Certainly he has most friendly feelings for Canada." 162 In a similar letter of 29 September, remarking that in the beginning he "was rather at sea as to what our position here should be," Kirkwood wrote:

My impression is that now our presence is not unwelcome here....

I haven't heard the reactions of Mr. Brun or Mr. Fischer to their Canadian visit; but Mr. Corp has been completely won over. He did not care for the United States, but fell completely in love with Canada....This should help a lot in influencing Governor Svane in due course....

All this is very much more gratifying and encouraging than was the dubious attitude during the early part of the summer, reflected perhaps with a note of pessimism and discouragement in my earlier letters. Certainly it now seems clearer that our policy of not asserting ourselves or appearing domineering or interfering is going to be to our advantage here, and will count for a great deal in our relationships. ${ }^{163}$

Kirkwood had an "extremely friendly" meeting with Governor Svane following the letter's arrival at Ivigtut (presumably from Godthaab) on 30 October.

I am under the impression that Mr. Corp had, in a preceding few hours conversation, laid the Canadian cryolite and aluminum industry situation clearly before Mr. Svane and had influenced him considerably....

Mr. Corp privately informed me that Mr. Svane's whole attitude had grealy $[$ sic] changed as a result of the close conversations on the cryolite supply question which they have held together in the past few days, and also in consequence of Mr. Svane's growing appreciation of the fact that Canada did not wish to interfere in Greenland. ${ }^{164}$

On what he expected would be the last ship to leave Greenland that year, Kirkwood sent Skelton a note concluding with the reassuring passage: "The past summer has gradually witnessed a general improvement in our relations with the Greenland authorities, who evinced doubt and distrust in the early stages of our mission here, but who have gradually had their confidence built up and their good will restored." 165

Thus, the positions of Canada and the United States vis-à-vis Greenland

\footnotetext{
162 Kirkwood to Keenleyside, 24 September 1940, RG 25, vol. 2731, file 267-J-40C, vol. 4, LAC.

163 Kirkwood to Keenleyside, 29 September 1940, RG 25, vol. 2731, file 267-J-40C, vol. 4, LAC.

164 Kirkwood to Secretary of State for External Affairs, Dispatch No. 30, 30 October 1940, RG 25, vol. 2731, file 267-J-40C, vol. 4, LAC.

${ }^{165}$ Kirkwood to Skelton, 20 November 1940, RG 25, vol. 2731, file 267-J-40C, vol. 4, LAC. King's diary entry for 22 October 1940 (947) commented on a visit from Kauffmann at Laurier House on that date as follows: "Interview with Mr. Koffmann [sic], Danish Minister to Washington, who spoke most appreciatively of Canada's management of affairs in Greenland."
} 
had been reversed. The United States was in the process of assuming in rather unwilling fashion the role of protector of Greenland, a role that Canada had taken preliminary gestures to obtain and had been denied. American popularity and prestige in the island were high, but already the US was experiencing some of the antipathy commonly vented upon protectors of any kind, whether invited, as she indeed was, or uninvited, as Canada would have been.

Canada and the United States continued to work out their individual and joint problems regarding Greenland in the months ahead, with British and Greenlandic officials keeping a watchful eye over developments. Despite official US policy to maintain a "Hands Off" approach towards Greenland in accordance with traditional American ideals, Smith observed, "there were as always influential elements which would have endorsed and supported an outright assumption of control." Furthermore, US officials remained vigilant in ensuring that Canada's interest in a prospective air corridor through Greenland which would connect the dominion to England did not lead Canada to build permanent air bases, leading Cordell Hull to sternly warn Canada on 23 September 1940:

Recent events on the East Coast of Greenland and in the waters adjacent thereto, impel me to inform you that the position of the Government of the United States as above set forth remains unchanged, and to add that in view of the geographical position of Greenland and the well known policies of the United States with respect to the Western Hemisphere, my Government could not acquiesce in any political, military or naval steps which constituted a permanent occupation or change in the status of Greenland. ${ }^{166}$

Instead, the US would play the role of protector. On 9 April 1941, Danish ambassador Kauffmann signed an agreement with the US government permitting the stationing of American troops and the construction of military infrastructure on the island. The Americans provided supplies, sent survey boats to patrol Greenland's east coast, and bombed or captured secret German weather stations installed on the island. A form of American, not Canadian, imperialism prevailed.

Canadian interest in Greenland continued during the war, but the emphasis shifted after the events described in Smith's article. The US Army Air Force established airbases on the island to patrol and support convoy operations in the North Atlantic, as well as serving as nodes within the northeast staging route or "Crimson Route" linking the Canadian North to Europe. Canada's contributions to these networks focused on its own territory and that of Newfoundland and Labrador. Furthermore, the discovery of synthetic alternatives to the natural cryolite found

\footnotetext{
166 Hull to Christie, 23 September 1940, see copy in RG 25, vol. 2731, file 267-J-40C, vol. 4, LAC. Almost identical notes were sent to the British and Norwegian Governments. See Langer and Gleason, Challenge to Isolation, 687.
} 
at Ivigtut meant that industrial motives for a robust Canadian presence lessened precipitously. "Once the Canadian aluminum industry's reliance on cryolite abated in 1943, however, so too did its interest in Greenland," historian Dawn Berry observes. "Alcan quickly developed a cost-effective alternative to cryolite, and broader Allied strategic geopolitical interests in Greenland replaced the acute supply needs of the Canadian aluminium industry during the war in the making of official policy." 167 As Smith documents in his full manuscript, Canada carefully monitored Greenland defence and security, weather stations, and political affairs until the liberation of Denmark in May 1945. But it did not seek to challenge growing US hegemony.

The Second World War revealed the geostrategic importance of Greenland in the North Atlantic. The Cold War affirmed it and amplified its importance as a "strategic base on a northern defense line" in an Arctic context as well. The United States' presence grew apace, with its weather station in the Greenlandic village of Pituffik evolving into Thule Air Base in 1952 - a base that essentially operates as a US enclave through to the present. The relocation of Inuit to build the base remains controversial, as does the stationing of American nuclear weapons in Greenland and environmental damage (including radioactive contamination caused by the nearby crash of a nuclear-armed B-52 bomber in 1968). ${ }^{168}$ Nevertheless, most Greenlandic politicians adopt a "pragmatic" attitude toward American military installations, which they argued also defend their security interests - and which is compatible with their interests as citizens who look to their state for military security against foreign adversaries. ${ }^{169}$

In 1953, the United States closed the consulate that it had established in Godthaab (Nuuk) thirteen years earlier. It reopened it in June 2020, in the wake of President Donald Trump's offer to purchase the island to secure its natural resources and capitalize on its strategic importance in an era of resurgent great power competition between the US, China, and Russia. The Kingdom of Denmark rejected the overture, dismissing it as "absurd" and insisting that Greenland is not for sale. ${ }^{170}$ Nevertheless, the US has announced a \$12 million US aid package for economic development, ${ }^{171}$ and the Danish Ministry of Foreign Affairs officially

\footnotetext{
167 Berry, "Cryolite, the Canadian aluminium industry and the American occupation of Greenland during the Second World War," 220.

168 R.E. Doel, Exploring Greenland: Cold War Science and Technology on Ice (Palgrave Macmillan, New York, 2016); and Kristen S. Kristensen and Jon Rahbek-Clemmensen, eds. Greenland and the International Politics of a Changing Arctic: Postcolonial Paradiplomacy between High and Low Politics (New York: Routledge, 2018). For a summary of the militarization of the Arctic during the Cold War, see, Peter Kikkert and P. Whitney Lackenbauer, "The Militarization of the Arctic to 1990," in The Palgrave Handbook of Arctic Policy and Politics, edited by Ken Coates and Carin Holroyd (Basingstoke: Palgrave Macmillan, 2020), 487-505.

169 J. Taagholt and J.C. Hansen, Greenland: Security Perspectives (Fairbanks: ARCUS, 2001), 61.

170 See, for example, Nick Allen, "US opens consulate in Greenland, months after Trump attempt to buy the territory rejected," National Post, 11 June 2020.

171 Conor Finnegan, “After Trump tried to buy Greenland, US gives island \$12M for economic
} 


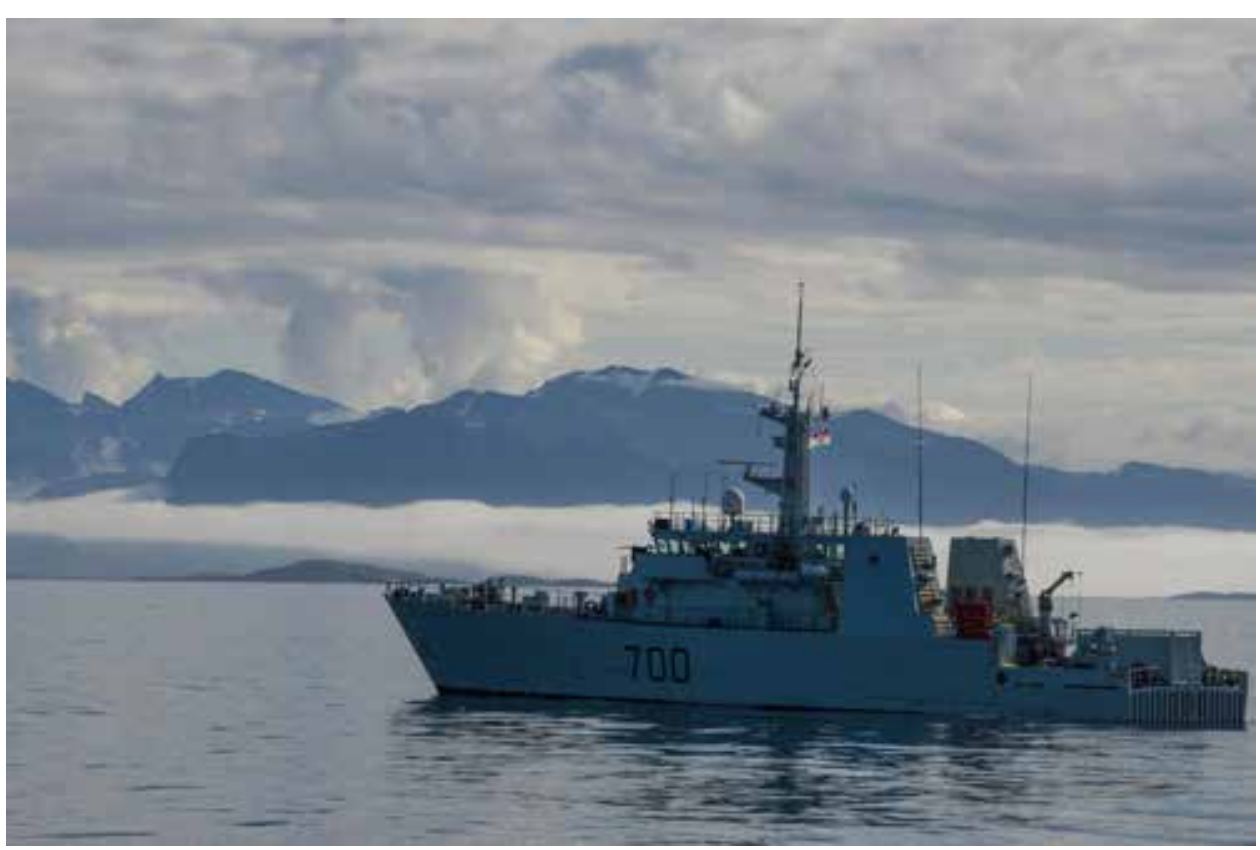

HMCS Kingston sails past the mountainous coast of Greenland during Operation Nanook in 2018. (Department of National Defence)

welcomed the US Department of Defense's "Statement of Intent on Defense Investments in Greenland" and its promise of future cooperation, "based on a mutual understanding that the United States' military presence in Greenland should benefit Greenland and the Greenlandic society to the maximum extent possible." 172 Amidst the rising chorus of Western concerns about China's vision of a "Polar Silk Road" running through the Arctic, Russian and Chinese militarization threatening the interests of the US and its allies in the region, strategic resources in the Arctic, and Greenland's political aspirations for full independence, the world's largest island remains a site of geopolitical intrigue. ${ }^{173}$ Canada has no aspirations to assume control over its eastern neighbour, but it certainly has vested interests in Greenland's security, supply chains, and the maritime approaches to northeastern North America.

Gordon W. Smith (1918-2000) was a historian who spent his early career as a

development," ABC News, 23 April 2020, https://abcnews.go.com/Politics/trump-buy-greenland-usisland-12m-economic-development/story?id=70305163.

172 Kingdom of Denmark, Ministry of Foreign Affairs, News release, 6 April 2021, https://um.dk/en/ news/newsdisplaypage/?newsid=bfc95523-956b-4df9-aba1-6e3f93cfb06d.

${ }^{173}$ See, for example, Justin Barnes, Heather Exner-Pirot, Lassi Heininen, and P. Whitney Lackenbauer, eds., China's Arctic Engagement: Following the Polar Silk Road to Greenland and Russia (Peterborough/ Akureyri: North American and Arctic Defence and Security Network Engage Series/ Arctic Yearbook, 2021). 
professor in Canada, the West Indies, and Africa. He devoted the last twentyfive years of his life to researching and writing the international history of the Canadian Arctic.

P. (Paul) Whitney Lackenbauer is Canada Research Chair (Tier 1) in the Study of the Canadian North and a Professor in the School for the Study of Canada at Trent University, Ontario, Canada. (Contact: pwhitneylackenbauer@trentu.ca) 